\title{
Membrane Incorporation, Channel Formation, and Disruption of Calcium Homeostasis by Alzheimer's $\beta$-Amyloid Protein
}

\author{
Masahiro Kawahara, ${ }^{1}$ Isao Ohtsuka, ${ }^{2}$ Shoko Yokoyama, ${ }^{3}$ Midori Kato-Negishi, ${ }^{4}$ \\ and Yutaka Sadakane ${ }^{1}$ \\ ${ }^{1}$ Department of Analytical Chemistry, School of Pharmaceutical Sciences, Kyushu University of Health and Welfare, \\ 1714-1 Yoshino-cho, Nobeoka-shi, Miyazaki 882-8508, Japan \\ ${ }^{2}$ Department of Pharmacognosy, School of Pharmaceutical Sciences, Kyushu University of Health and Welfare, \\ 1714-1 Yoshino-cho, Nobeoka-shi, Miyazaki 882-8508, Japan \\ ${ }^{3}$ Department of Pharmaceutical Science, School of Pharmaceutical Sciences, Kyushu University of Health and Welfare, \\ 1714-1 Yoshino-cho, Nobeoka-shi, Miyazaki 882-8508, Japan \\ ${ }^{4}$ Institute of Industrial Science (IIS), The University of Tokyo, 4-6-1 Komaba, Meguro-ku, Tokyo 153-8904, Japan
}

Correspondence should be addressed to Masahiro Kawahara, kawamasa@phoenix.ac.jp

Received 16 October 2010; Revised 22 December 2010; Accepted 27 January 2011

Academic Editor: Anne Eckert

Copyright ( $) 2011$ Masahiro Kawahara et al. This is an open access article distributed under the Creative Commons Attribution License, which permits unrestricted use, distribution, and reproduction in any medium, provided the original work is properly cited.

Oligomerization, conformational changes, and the consequent neurodegeneration of Alzheimer's $\beta$-amyloid protein (A $\beta \mathrm{P}$ ) play crucial roles in the pathogenesis of Alzheimer's disease (AD). Mounting evidence suggests that oligomeric A $\beta$ Ps cause the disruption of calcium homeostasis, eventually leading to neuronal death. We have demonstrated that oligomeric A $\beta$ Ps directly incorporate into neuronal membranes, form cation-sensitive ion channels ("amyloid channels"), and cause the disruption of calcium homeostasis via the amyloid channels. Other disease-related amyloidogenic proteins, such as prion protein in prion diseases or $\alpha$-synuclein in dementia with Lewy bodies, exhibit similarities in the incorporation into membranes and the formation of calcium-permeable channels. Here, based on our experimental results and those of numerous other studies, we review the current understanding of the direct binding of $\mathrm{A} \beta \mathrm{P}$ into membrane surfaces and the formation of calcium-permeable channels. The implication of composition of membrane lipids and the possible development of new drugs by influencing membrane properties and attenuating amyloid channels for the treatment and prevention of $\mathrm{AD}$ is also discussed.

\section{Introduction}

Alzheimer's disease $(\mathrm{AD})$ is a severe type of senile dementia, affecting a large portion of elderly people worldwide. It is characterized by profound memory loss and inability to form new memories. The pathological hallmarks of $\mathrm{AD}$ are the presence of numerous extracellular deposits, termed senile plaques, and intraneuronal neurofibrillary tangles (NFTs). The degeneration of synapses and neurons in the hippocampus or cerebral cortex is also observed [1]. The major components of NFTs are phosphorylated tau proteins, and that of senile plaques are $\beta$-amyloid proteins (A $\beta$ Ps).
Although the precise cause of $\mathrm{AD}$ remains elusive, it is widely accepted that oligomerization of $\mathrm{A} \beta \mathrm{P}$ and the consequent neurodegeneration might be the cause of neuronal death in $\mathrm{AD}$ patients $[2,3]$.

There is considerable interest regarding the mechanism by which $\mathrm{A} \beta \mathrm{Ps}$ cause neurodegeneration. $\mathrm{A} \beta \mathrm{Ps}$ have been reported to cause various adverse effects on neuronal survivals, such as the production of reactive oxygen species, the induction of cytokines, the induction of endoplasmic reticulum (ER) stresses, and the abnormal increase in intracellular calcium levels $\left(\left[\mathrm{Ca}^{2+}\right]_{\mathrm{i}}\right)[4]$. These adverse effects are complex and may be interwoven. Of these effects, 
the disruption of calcium homeostasis could be the earliest and primary event, since $\mathrm{Ca}^{2+}$ ions are essential for various neuronal functions. The elevation of $\left[\mathrm{Ca}^{2+}\right]_{\mathrm{i}}$ induces various apoptotic pathways.

There are several mechanisms that account for $\mathrm{A} \beta \mathrm{P}$ induced calcium dyshomeostasis [5-7]. Of these, we focus on the "amyloid channel hypothesis"-direct insertion into membranes of $\mathrm{A} \beta \mathrm{P}$, formation of channels (pores), and disruption of calcium homeostasis via unregulated cytotoxic channels may be the molecular basis of its neurotoxicity [810]. Other amyloidogenic disease-related proteins, such as the prion protein or $\alpha$-synuclein, also exhibit similarities in the formation of amyloid channels and in the disruption of calcium homeostasis.

We review here the current understanding of the "amyloid channel hypothesis" based on our recent results and those of other researchers. It is widely recognized that the composition of membrane lipids influences the formation of amyloid channels by affecting the interaction between peptides and membranes. The possible development of new drugs by influencing membrane lipid properties and attenuating amyloid channels for the treatment and prevention of $\mathrm{AD}$ is also discussed.

\section{Conformational Changes of $A \beta P$ and Its Neurotoxicity}

$\mathrm{A} \beta \mathrm{P}$ is a small peptide with $39-43$ amino acid residues. It is secreted by the cleavage of the N-terminal of a large precursor protein (amyloid precursor protein; APP) by $\beta$ secretase $(\beta$-site APP cleaving enzyme; BACE), followed by the intramembrane cleavage of its C-terminal by $\gamma$ secretase. This different C-terminal cleavage of APP causes various truncated $\mathrm{A} \beta \mathrm{Ps}$, such as $\mathrm{A} \beta \mathrm{P}(1-40)$, the first 40 amino acid residues, or $\mathrm{A} \beta \mathrm{P}(1-42)$. Genetic studies of earlyonset cases of familial AD indicated that APP mutations and $\mathrm{A} \beta \mathrm{P}$ metabolism are associated with $\mathrm{AD}$ [11]. It was also revealed that mutations in the presenilin genes account for the majority of cases of early-onset familial AD [12]. Presenilins have been revealed to be $\gamma$-secretases [13], and their mutations influence the production of $\mathrm{A} \beta \mathrm{P}$ and its neurotoxicity [14].

Yankner et al. reported that $\mathrm{A} \beta \mathrm{P}(1-40)$ caused the death of cultured rat hippocampal neurons or neurodegeneration in the brains of experimental animals [15]. However, the neurotoxicity of $\mathrm{A} \beta \mathrm{P}$ has been a subject of much debate because of its peculiar characteristics. $\mathrm{A} \beta \mathrm{P}$ is a hydrophobic peptide with an intrinsic tendency to self-assemble to form oligomers (aggregates). In the aqueous solution, monomeric form of $\mathrm{A} \beta \mathrm{P}$ exhibits a random coil structure. Meanwhile, under incubation at $37^{\circ} \mathrm{C}$ for several days (aging), $\mathrm{A} \beta \mathrm{Ps}$ form aggregates (oligomers) with $\beta$-pleated sheet structures. Pike et al. revealed that aged $\mathrm{A} \beta \mathrm{P}(1-40)$ was considerably more toxic to cultured neurons as compared to freshly prepared $\mathrm{A} \beta \mathrm{P}(1-40)$ [16]. The neurotoxicity of $\mathrm{A} \beta \mathrm{P}$ was correlated with their $\beta$-sheet contents, as observed by circular dichroism (CD) spectroscopy [17]. Jarrett and Lansbury demonstrated that $\mathrm{A} \beta \mathrm{P}$ forms oligomers by a nucleation-dependent process and that $\mathrm{A} \beta \mathrm{P}(1-42)$ becomes "seeds" in the aggregates and enhances the oligomerization of $\mathrm{A} \beta \mathrm{P}(1-40)$ - suggesting the significance of intracellular $\mathrm{N}$ - and C-terminal heterogeneity [18].

Recent detailed analysis using size-exclusion chromatography, gel electrophoresis, and atomic force microscopy (AFM) has demonstrated that there are several stable types of soluble oligomers: naturally occurring soluble oligomers (dimers or trimers), ADDLs (A $\beta$ P-derived diffusible ligands), $\mathrm{A} \beta \mathrm{P}$ globulomers, or protofibrils. Increasing evidence suggests that soluble amyloid oligomers cause synaptic and neuronal degeneration [19-21]. The identification of toxic $\mathrm{A} \beta \mathrm{P}$ spices is crucial and has been a subject of scientific debates. Hartley et al. separated aggregated $\mathrm{A} \beta \mathrm{P}(1-40)$ into low-molecular-weight (mainly monomer), protofibrillar, and fibril fractions by size-exclusion chromatography, and found that the protofibrillar fraction caused marked changes in the electrical activity of cultured neurons and neurotoxicity [22]. Walsh et al. reported that the naturally secreted (derived from the cerebrospinal fluid of AD patients), SDS-stable low-molecular-weight oligomers (dimers, trimers, or tetramers), but not $\mathrm{A} \beta \mathrm{P}$ monomers or larger aggregates, inhibit long-term potentiation (LTP) and cause the loss of dendritic spines and synapses [23]. Lacor and colleagues reported that $\mathrm{A} \beta \mathrm{P}$-derived diffusible ligands (ADDLs) inhibited LTP and exhibited adverse effects on synaptic plasticity, such as abnormal spine morphology, decreased spine density, and decreased synaptic proteins [24]. Recently, Jan et al. found that mixtures of monomeric and heterogenous oligomers $\mathrm{A} \beta \mathrm{P}(1-42)$ were more toxic than monomeric, protofibrillar fractions or fibril [25]. They demonstrated that $\mathrm{A} \beta \mathrm{P}$ toxicity depends on the ability to grow and undergo fibril formation of prefibrillar aggregates and monomer. The process of fibril formation and its contribution to toxicity is complicated. Mature fibrils are regarded to be less toxic compared to soluble oligomers $[26,27]$, although there are some cases fibrils direct cause toxicity $[28,29]$. It is possible that the toxicity of mature fibrils can result from the leakage of toxic short protofibrils or oligomers [27] or from its size-dependent mechanical properties of accumulations in the normal tissues [30].

As synaptic plasticity is crucial for the process of memory formation, synaptic degeneration (synaptotoxicity) is involved in the early stages of AD. Indeed, the number of synapses is strongly correlated with the level of memory impairment in $\mathrm{AD}$ patients, rather than the number of senile plaques or NFTs, [31]. Considering that $\mathrm{A} \beta \mathrm{P}$ is secreted in the cerebrospinal fluid (CSF) of young individuals as well as in aged or dementia patients [32], factors that accelerate or inhibit the oligomerization may play essential roles in the pathogenesis of AD. Various factors, such as the concentration of peptides, the oxidations, mutations, and racemization of $\mathrm{A} \beta \mathrm{P}, \mathrm{pH}$, composition of solvents, temperature, and trace elements, can influence the oligomerization processes [33]. Among these factors, $\mathrm{Al}$ and other trace elements are of particular interest because of the epidemiological link with AD [34]. 


\section{A $\beta$ P-Induced Neurotoxicity and the Disruption of Calcium Homeostasis}

There is considerable interest regarding in the mechanism by which $\mathrm{A} \beta \mathrm{P}$ s cause neurodegeneration. Of various adverse effects caused by $\mathrm{A} \beta \mathrm{P}$, calcium dyshomeostasis could be the earliest and primary adverse event, since $\mathrm{Ca}^{2+}$ ions are essential for various key enzymes such as kinases, phosphatases, and proteases. Once neuronal calcium homeostasis was disrupted and $\left[\mathrm{Ca}^{2+}\right]_{\mathrm{i}}$ was changed, various apoptotic pathways such as calpain and caspase activation occurred, leading to neuronal death. The disruption of calcium homeostasis could trigger the membrane disruption, the formation of reactive oxygen species (ROS), and induce other adverse effects which are often observed after exposure to $A \beta$ P. It is widely known that the increase in $\left[\mathrm{Ca}^{2+}\right]_{\mathrm{i}}$ induced changes in the number of spines, their morphology, and the number of synapses [35]. Considering that $\mathrm{A} \beta \mathrm{P}$ and $\mathrm{APP}$ coexist in the synapses [36], calcium imbalances in the synaptic compartment could directly influence neuronal activities and cause synaptic impairment (synaptotoxicity). $\mathrm{Ca}^{2+}$ is also implicated in the phosphorylation of the tau protein [37] or in APP sequestration [38]. Fibroblasts derived from $\mathrm{AD}$ patients exhibited different $\mathrm{Ca}^{2+}$ mobilization compared to those derived from age-matched control subjects [39]. Mounting evidence indicates that calcium dysregulation occurs in $\mathrm{AD}$ or in $\mathrm{A} \beta \mathrm{P}$-intoxicated neurons $[40,41]$.

There are several possible mechanisms by which $\mathrm{A} \beta \mathrm{Ps}$ interact with neurons and disrupt calcium homeostasis. Demuro et al. reviewed the $\mathrm{A} \beta \mathrm{P}$-induced calcium dyshomeostasis and its toxicity in the context of calcium signaling, and outlined three major mechanisms: the activation of some type of cell surface receptors coupled to $\mathrm{Ca}^{2+}$ influx, the disruption of membrane integrity, and the direct incorporation into the membrane to create unregulated cytotoxic channels (pores) [5].

A $\beta$ Ps were reported to bind to NMDA ( $N$-methyl Daspartate-)type or AMPA ( $\alpha$-amino-3-hydroxy-5-methy-lisoxazole4-propionic acid)-type glutamate receptors [42], or nicotinic acetylcholine receptors [43]. All of these receptors were highly $\mathrm{Ca}^{2+}$ permeable. Furthermore, $\mathrm{A} \beta \mathrm{P}$ influences voltage gated $\mathrm{Ca}^{2+}$ channels [44] or inositol triphosphate $\left(\mathrm{IP}_{3}\right)$ receptor [45]. It is widely recognized that presenilins are involved in capacitative $\mathrm{Ca}^{2+}$ entry, in $\mathrm{ER} \mathrm{Ca}^{2+}$ signaling, or in mitochondrial $\mathrm{Ca}^{2+}$ signaling, and that their mutations affect the calcium-regulated functions [46-49]. Therefore, disturbances of $\mathrm{ER} \mathrm{Ca}^{2+}$ stress or mitochondrial $\mathrm{Ca}^{2+}$ homeostasis may be involved in the pathogenesis of $\mathrm{AD}$.

\section{Channel Formation by A $\beta$ P: Possible Mechanisms of Calcium Dyshomeostasis}

In 1993, Arispe et al. first demonstrated that $\mathrm{A} \beta \mathrm{P}(1-40)$ directly incorporates into artificial planar lipid bilayer membranes and forms cation selective ion channels [50, 51]. These "amyloid channels" were revealed to be giant multilevel pores and were permeable to $\mathrm{Ca}^{2+}$. Their activity was blocked by $\mathrm{Zn}^{2+}$, which is abundantly present in the brain [52]. Other neurotoxic peptide fragments of $\mathrm{A} \beta \mathrm{P}$, including $\mathrm{A} \beta \mathrm{P}(25-35)$ and $\mathrm{A} \beta \mathrm{P}(1-42)$, were reported to form calcium-permeable pores on artificial lipid bilayers as well as $\mathrm{A} \beta \mathrm{P}(1-40)[53,54]$. The characteristics of amyloid channels formed by $\mathrm{A} \beta \mathrm{P}(1-40)$ and $\mathrm{A} \beta \mathrm{P}(1-42)$ exhibited similarities: multilevel and giant pores $(\sim 5 \mathrm{nS})$ and cation (including $\mathrm{Ca}^{2+}$ ) selectivity. The activity of both channels could be blocked by $\mathrm{Zn}^{2+}$. Fraser et al. reported that the toxic C-terminal fragment of $\mathrm{APP}\left(\mathrm{CT}_{105}\right.$; containing a full length of $\mathrm{A} \beta \mathrm{P}$ ) induced channel currents on membranes of Xenopus oocytes [55].

Durell et al. proposed a 3D structural model of amyloid channels obtained from a computer simulation of the secondary structure of $\mathrm{A} \beta \mathrm{P}(1-40)$ in membranes, which showed 5 to 8 mers aggregating to form pore-like structures on the membranes [56]. Strodel et al. proposed a model of $\mathrm{A} \beta \mathrm{P}(1-42)$ pores which consist of tetrameric and hexameric $\beta$-sheet subunits from the observations in NMR [57]. These models are consistent with morphological observations using high-resolution AFM that demonstrated that $\mathrm{A} \beta \mathrm{Ps}$ form pore-like structures on mica plates or on membranes [58-60].

A large number of studies have demonstrated that $A \beta P$ directly binds to membranes, causes membrane perturbation or disruption, and induces the increase in permeability to ions (including $\mathrm{Ca}^{2+}$ ) or large molecules [61-64]. The findings of Demuro et al. are particularly interest in this context [65]. They investigated effects of $\mathrm{A} \beta \mathrm{P}$ and other amyloid peptides in various aggregation states, and revealed that oligomeric peptides caused the rapid increase in $\left[\mathrm{Ca}^{2+}\right]_{\mathrm{i}}$ or the membrane disruption, whereas monomers and fibrils did not.

Furthermore, the presence of pore-like structures of $A \beta P$ s was demonstrated in the neuronal cell membrane of the brains of $\mathrm{AD}$ patients and of $\mathrm{AD}$-model mice. Using highresolution transmission electron microscopy, Inoue observed in situ $\mathrm{A} \beta \mathrm{P}$ pores in the neuronal cell membrane in $\mathrm{AD}$ brains [66]. Kayed et al. reported that the annular protofibrils (APFs) of $\mathrm{A} \beta \mathrm{P}$ exhibit ring-shaped and pore-like structures [67]. The age-dependent accumulation of APFs was observed on the membranes of AD model mice (APP transgenic mice; APP23) [68].

To determine whether or not $\mathrm{A} \beta \mathrm{Ps}$ form channels on neuronal cell membranes as well as on artificial lipid bilayers, we employed membrane patches from immortalized hypothalamic neurons (GT1-7 cells). GT1-7 cells are derived from murine hypothalamic neurons by site-directed tumorigenesis and exhibit various neuronal characteristics, such as the extension of neuritis, and the expression of various neuron-specific proteins or receptors [69]. Within 330 min of the addition of $\mathrm{A} \beta \mathrm{P}(1-40)$ to the bath solution, the current derived from the amyloid channels appeared across the excised membrane patches [70]. However, $\mathrm{A} \beta \mathrm{P}(40-1)$, a peptide bearing the reversed sequence of $\mathrm{A} \beta \mathrm{P}(1-40)$, did not form any channels. The characteristics of amyloid channels formed on the GT1-7 cell membranes were considerably similar to those observed on artificial lipid bilayers: cation selective, multilevel, voltage independent, and long-lasting. Its channel activity was inhibited by the addition of $\mathrm{Zn}^{2+}$, 
and recovered by a zinc chelator-o-phenanthroline. Furthermore, Sepulveda et al. revealed that $\mathrm{A} \beta \mathrm{P}(1-40)$ formed perforations on membranes excised from hippocampal neurons and induced currents [71]. The effect of $\mathrm{A} \beta \mathrm{P}$ was similar to that of gramicidin and amphotericin which are commonly used to perforate neuron membranes.

\section{Disruption of Calcium Homeostasis Caused by Amyloid Channels}

In order to test the validity of the amyloid channel hypothesis, we examined whether $\mathrm{A} \beta \mathrm{P}$ alters the $\left[\mathrm{Ca}^{2+}\right]_{\mathrm{i}} \mathrm{lev}-$ els of GT1-7 cells under the same conditions, using a high-resolution multisite video imaging system with calcium-sensitive fluorescent dye, fura-2 [71-74]. Shown in Figure 1(a) are pseudocolor images of levels indicating the $\left[\mathrm{Ca}^{2+}\right]_{\mathrm{i}}$ of GT1-7 cells before and after exposure to $\mathrm{A} \beta \mathrm{P}(1-40)$. Shortly after exposure to $\mathrm{A} \beta \mathrm{P}(1-40)$, a marked increase in $\left[\mathrm{Ca}^{2+}\right]_{\mathrm{i}}$ occurred among many, but not all GT1-7 cells. Figure $1(\mathrm{~b})$ depicts $\mathrm{A} \beta \mathrm{P}(1-40)$-induced temporal changes of the $\left[\mathrm{Ca}^{2+}\right]_{\mathrm{i}}$ of 50 randomly chosen GT1-7 cells in the same field of view. Furthermore, we compared responses to $\mathrm{A} \beta \mathrm{P}$ and the related peptides (Figure $2(\mathrm{a})$ ). Although a marked increase in $\left[\mathrm{Ca}^{2+}\right]_{\mathrm{i}}$ was caused by $\mathrm{A} \beta \mathrm{P}(1-$ 40) (line $(A)$ ) or by $\mathrm{A} \beta \mathrm{P}(1-42)$ (line $(C)$ ), control peptides such as $\mathrm{A} \beta \mathrm{P}(40-1)$ caused no remarkable changes (line $(B)$ ).

As previously discussed, there are several mechanisms that could account for the elevations in $\left[\mathrm{Ca}^{2+}\right]_{\mathrm{i}}$ induced by $\mathrm{A} \beta \mathrm{P}$. However, our detailed quantitative analysis of the $\mathrm{A} \beta \mathrm{P}-$ induced calcium influx suggests that $A \beta P$-induced $\left[\mathrm{Ca}^{2+}\right]_{\mathrm{i}}$ changes occurred via unregulated amyloid channels and not by endogenous receptor-mediated pathways. This is supported by 4 major pieces of evidence.

First, the $\mathrm{A} \beta \mathrm{P}$-induced $\left[\mathrm{Ca}^{2+}\right]_{\mathrm{i}}$ rise was highly heterogeneous among genetically identical GT1-7 cells. Even in the same field of view, exposure to the same peptide solution produced different change patterns in the $\left[\mathrm{Ca}^{2+}\right]_{\mathrm{i}}$ levels as shown in Figure 1(b). Although $\mathrm{A} \beta \mathrm{P}(1-40)$ induced an increase in the $\left[\mathrm{Ca}^{2+}\right]_{\mathrm{i}}$ levels either instantly or after some delay, the magnitude and latency differed. Certain other adjacent cells still did not exhibit any responses. It is possible that the membrane binding of $\mathrm{A} \beta \mathrm{P}$ is crucial for the cell-to-cell heterogeneity. Simakova and Arispe revealed that the surface phosphatidylserine and the cytosolic ATP levels are important determinants of the binding of $\mathrm{A} \beta \mathrm{P}$ to membranes [75]. To analyze $\mathrm{A} \beta \mathrm{P}$-induced calcium influx quantitatively under the cell-to-cell heterogeneous condition, we compared the peak increase in $\left[\mathrm{Ca}^{2+}\right]_{\mathrm{i}}\left(\Delta\left[\mathrm{Ca}^{2+}\right]_{\mathrm{i}}\right)$ induced by $\mathrm{A} \beta$ Ps and its latency (the lag between the $\left[\mathrm{Ca}^{2+}\right]_{\mathrm{i}}$ increase and the time of $\mathrm{A} \beta \mathrm{P}$ addition) in each cell. This multisite fluorometry system enables the simultaneous longterm observation of temporal changes in $\left[\mathrm{Ca}^{2+}\right]_{i}$ of more than 50 neurons. Second, the average $\Delta\left[\mathrm{Ca}^{2+}\right]_{\mathrm{i}}$ was increased in a dose-dependent manner of $\mathrm{A} \beta \mathrm{P}$, while the average latency decreased (Figures 2(b) and 2(c)). It is unlikely that the dose-dependent decrease in the latency occurs through the receptor-mediated pathways. These features are considerably similar to those observed in relation to peptide channels formed on membranes $[71,76]$. The concentration of $\mathrm{A} \beta \mathrm{P}$ required to form amyloid channels is higher $(\sim \mu \mathrm{M})$ than the $\mathrm{A} \beta \mathrm{P}$ concentration found in the brain. However, it is plausible that it requires a longer period for the lower concentration of $\mathrm{A} \beta \mathrm{P}$ to cause changes in $\left[\mathrm{Ca}^{2+}\right]_{i}$.

Third, the A $\beta$ P-induced increase in $\left[\mathrm{Ca}^{2+}\right]_{\mathrm{i}}$ was not influenced by the addition of the $\mathrm{Na}^{+}$channel blocker (tetrodotoxin), the $\mathrm{Ca}^{2+}$ channel blocker (nifedipine), the antagonist of NMDA-type glutamate receptor (D-APV), or the antagonist of $\gamma$-aminobutyric acid (GABA) receptor (bicuculline) [77].

Fourth, D-A $\beta \mathrm{P}(1-40), \mathrm{A} \beta \mathrm{P}(1-40)$ composed of all Damino acid residues, also caused the elevation of $\left[\mathrm{Ca}^{2+}\right]_{i}$ in a manner similar to $\mathrm{A} \beta \mathrm{P}(1-40)$ (Figure $2(\mathrm{a})$ line $(D)$ ). This is consistent with the findings of Cribbs et al. suggesting that all-D-enantiomers of $\mathrm{A} \beta \mathrm{P}$ possess the similar toxicity compared to all-L- A $\beta \mathrm{P}[78]$.

Therefore, it is plausible that $\mathrm{A} \beta \mathrm{P}$-induced $\left[\mathrm{Ca}^{2+}\right]_{\mathrm{i}}$ changes occurred through amyloid channels by direct incorporation into membranes, but not through some receptormediated pathways.

These results strongly support the hypothetical idea termed "amyloid channel hypothesis," namely, that the direct incorporation of $\mathrm{A} \beta \mathrm{Ps}$ and the subsequent imbalances of calcium and other ions through amyloid channels may be the primary event in $\mathrm{A} \beta \mathrm{P}$ neurotoxicity [8-10].

\section{Channel Formation and $\left[\mathrm{Ca}^{2+}\right]_{\mathrm{i}}$ Influx by Other Amyloidogenic Peptides}

Pore formation-induced cytotoxicity, such as in the cases of certain toxins or venoms, is commonly observed in our biological system. For example, the $\alpha$-toxin of Staphylococcus aureus, which is secreted as a single-chain, water-soluble $33 \mathrm{kDa}$ molecule, nonspecifically binds to membranes to form pore-like structures composed of hexamers with $\beta$ sheet structures, causing $\mathrm{Ca}^{2+}$ influx through the pores [79]. Magainin 2, a 26-residue antimicrobial peptide obtained from Xenopus laevis, forms transmembrane $\mathrm{Ca}^{2+}$-permeable pores on bacterial cell membranes [80]. Other antimicrobial peptides such as melitin (a bee venom composed of 28 amino acids), or antibiotics such as amphotericin and gramicidin were also reported to form transmembrane pores and to cause cell lysis [81]. In this respect, $A \beta P$ and other amyloidogenic proteins might share the similar mechanism with these pore-forming peptides. Indeed, Soscia et al. demonstrated that $\mathrm{A} \beta \mathrm{P}$ exerts antimicrobial activity against 8 common and clinically relevant microorganisms [82].

Furthermore, electrophysiological and morphological studies have revealed that other disease-related proteinstermed amyloidogenic proteins_-exhibit similarities in the formation of amyloid channels as well as $\mathrm{A} \beta \mathrm{P}$.

Prion diseases, including human kuru, Creutzfeldt-Jakob disease, and bovine spongiform encephalopathy (BSE), are associated with the conversion of a normal prion protein $\left(\mathrm{PrP}^{\mathrm{C}}\right)$ to an abnormal scrapie isoform $\left(\mathrm{PrP}^{\mathrm{SC}}\right)$ [83]. The $\beta$ sheet region of $\mathrm{PrP}^{\mathrm{SC}}$ is suggested to play a crucial role in its transmissible degenerative processes. A peptide fragment 


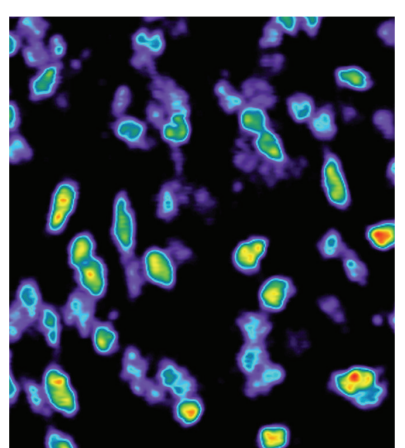

(A)

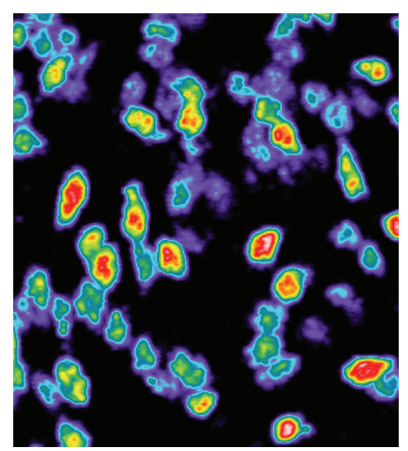

(B)

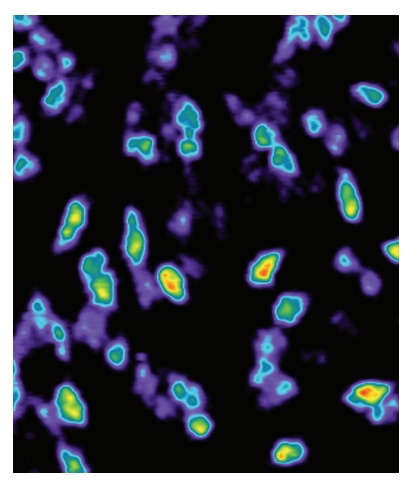

(C)

(a)

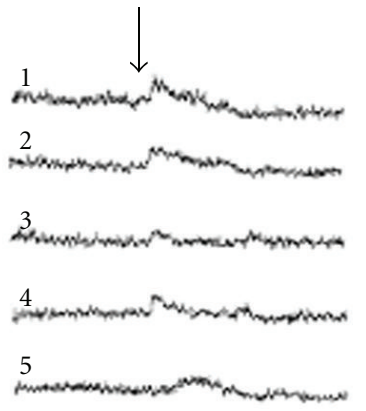

6
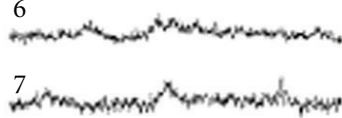

8

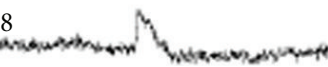

9

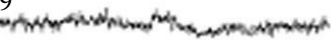

10
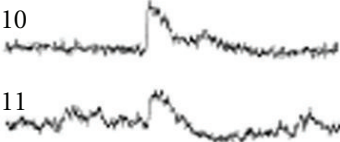

12

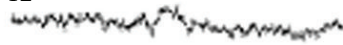

13

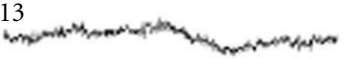

14
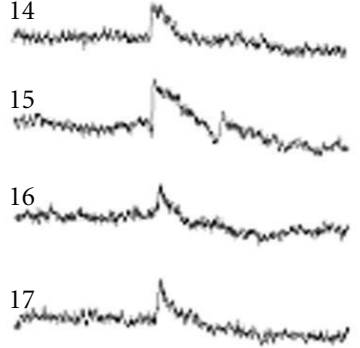

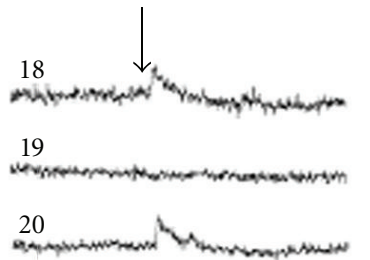

21

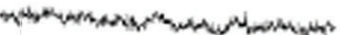

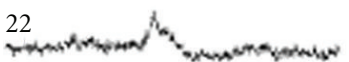

23

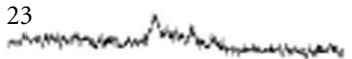

24
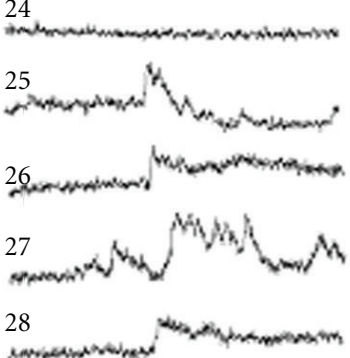

sestis
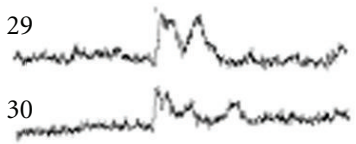

31
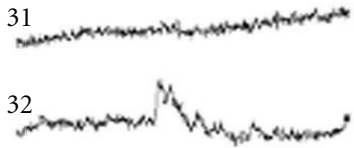

33
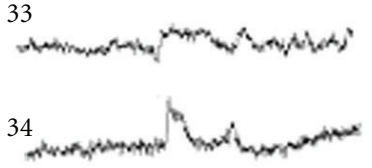

(b)

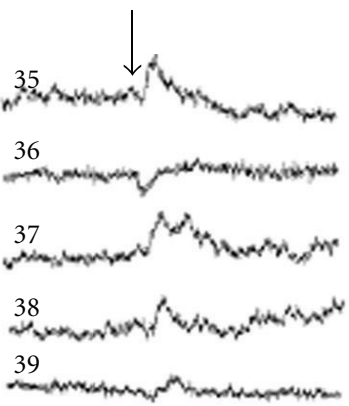

40

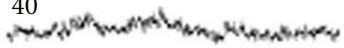

41

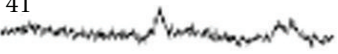

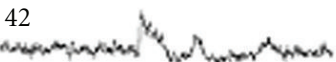

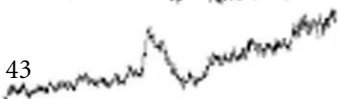

44
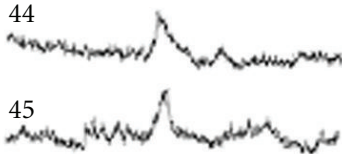

46
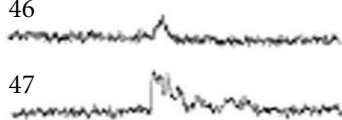

48
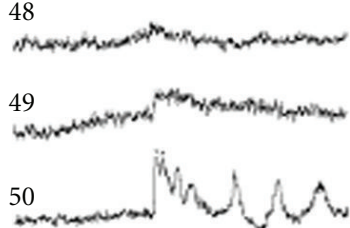

$\int_{60 \mathrm{~s}} 100 \mathrm{nM}$

Figure 1: Effects of A $\beta$ P on temporal changes of $\left[\mathrm{Ca}^{2+}\right]_{\mathrm{i}}$. (a) Pseudocolor images of $\left[\mathrm{Ca}^{2+}\right]_{\mathrm{i}}$ during exposure to A $\beta \mathrm{P}(1-40)$ in $\mathrm{GT} 1-7$ cells. A solution of $\mathrm{A} \beta \mathrm{P}(1-40)(10 \mu \mathrm{M})$ was applied onto fura-2-loaded GT1-7 cells. Temporal changes of fluorescence intensities corresponding to increases in $\left[\mathrm{Ca}^{2+}\right]_{\mathrm{i}}$ were analyzed. (A) 1 min before exposure to $\mathrm{A} \beta \mathrm{P}(1-40)$; (B) 20 sec after exposure; (C) 5 min after exposure. (b) Temporal changes of randomly chosen 50 GT1-7 cells in the same field of view before and after the exposure to A $\beta \mathrm{P}(1-40)$ are depicted. The arrow indicates the time of peptide addition.

of PrP corresponding to residues 106-126 (PrP106-126) coincides with the proposed $\beta$-sheet structures and has been reported to cause death in cultured hippocampal neurons [84]. Lin et al. reported that PrP106-126 forms cation permeable pores in artificial lipid bilayers [85]. The activity of $\operatorname{PrP}$ channels was also blocked by $\mathrm{Zn}^{2+}$. Kourie and Culverson investigated the detailed characteristics of channels formed by PrP106-126, concluding that it was directly incorporated into lipid bilayers and formed cation selective, copper-sensitive ion channels [86]. They also revealed that quinacrine, a potent therapeutic drug, possibly blocks amyloid channels induced by PrP106-126.
The aggregation and fibrillation of $\alpha$-synuclein has been implicated in the formation of abnormal inclusions, termed Lewy bodies, and the etiology of dementia with Lewy bodies (DLB) [87]. Nonamyloid component (NAC), a fragment peptide of $\alpha$-synuclein, accumulates in Alzheimer's senile plaques and causes apoptotic neuronal death [88]. Lashuel et al. demonstrated by electron microscope observation that $\alpha$-synuclein forms annular pore-like structures [89].

The elongation of a polyglutamine-coding CAG triplet repeat in the responsible genes is based on the pathogenesis of triplet-repeat disease such as Huntington's disease or Machado-Joseph disease [90]. Hirakura et al. reported that 
(A)

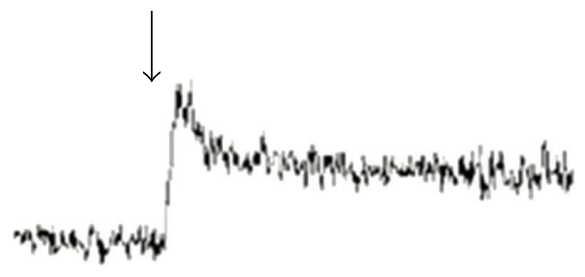

(B)

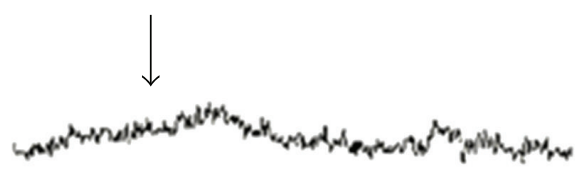

(C)

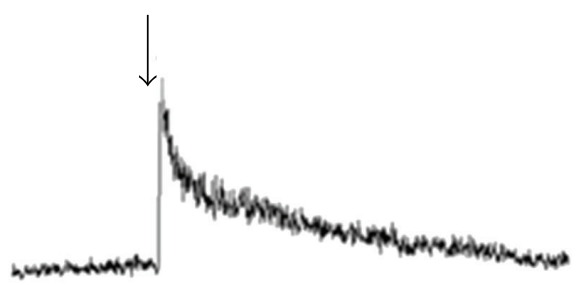

(D)

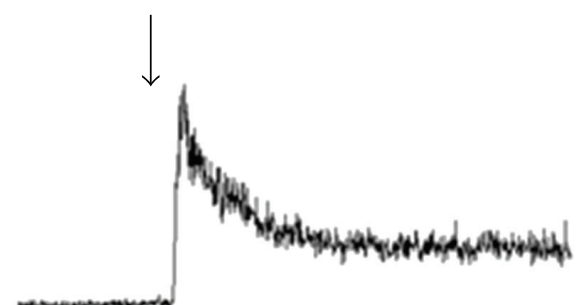

(a)

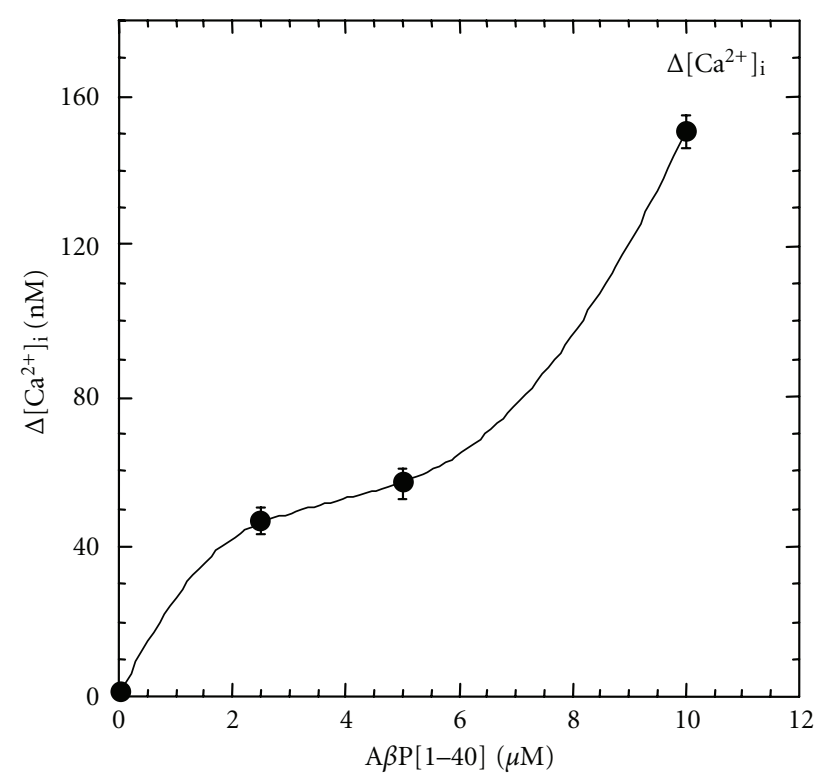

(b)

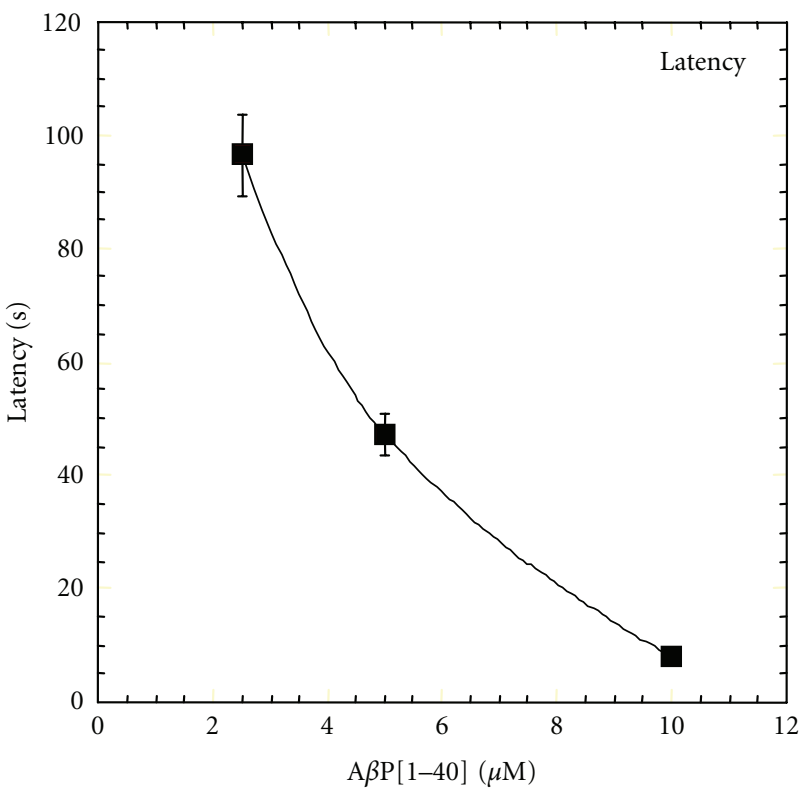

(c)

FIgURE 2: Characteristics of A $\beta$ P-induced elevations in $\left[\mathrm{Ca}^{2+}\right]_{i}$. (a) Typical time course of $\left[\mathrm{Ca}^{2+}\right]_{\mathrm{i}}$ prior to 2 min and after 3 min of the application of the peptide is depicted. Concentration is $10 \mu \mathrm{M}$ for all peptides used. (A) A $\beta \mathrm{P}(1-40)$; (B) $\mathrm{A} \beta \mathrm{P}(40-1)$; (C) A $\beta \mathrm{P}(1-42)$; (D) D$\mathrm{A} \beta \mathrm{P}(1-40)$. The arrow indicates the time of peptide addition. (b) and (c) Dose-dependence of the increase in $\left[\mathrm{Ca}^{2+}\right]_{\mathrm{i}}$. Typical responses of $\left[\mathrm{Ca}^{2+}\right]_{\mathrm{i}}$ in cultured neurons following exposure to various concentrations of $\mathrm{A} \beta \mathrm{P}(1-40)(2.5 \sim 10 \mu \mathrm{M})$. The peak increase in $\left[\mathrm{Ca}^{2+}\right]_{\mathrm{i}}\left(\Delta\left[\mathrm{Ca}^{2+}\right]_{\mathrm{i}}\right)$ in each cell (b) and the latency after exposure to $\mathrm{A} \beta \mathrm{P}(1-40)$ were analyzed in more than 50 neurons in field of view $(360 \times 420 \mu \mathrm{m})$ cultured neurons (mean \pm S.E.M., $n=300$ ).

polyglutamine formed ion channels in lipid bilayers [91]. Human amylin (IAAP, islet amyloid peptide) forms amyloid fibrils, accumulates in the islet of patients of type 2 diabetes mellitus, and causes cytotoxicity in islet cells or in cultured hippocampal neurons. However, rat amylin did not cause cytotoxicity nor form $\beta$-sheet structures, in spite of the $95 \%$ similarity in the amino acid sequence [92]. Mirzabeko et al. revealed that human amylin formed ion channels on liposomes, but rat amylin did not [93]. Calcitonin is a 32amino acid polypeptide hormone, which is produced by the thyroid C-cells. It is involved in calcium homeostasis and is associated with medullary carcinoma of the thyroid [94]. Using transmission electron microscopy (TEM) observation on liposome, Diociaiuti et al. found that calcitonin oligomers exhibit annular pore-like structures [95]. Lal et al. investigated the oligomerization and conformational changes of $\mathrm{A} \beta \mathrm{P}$, synuclein, amylin, and other amyloidogenic proteins using gel electrophoresis and AFM imaging, and demonstrated that these amyloidogenic proteins form annular channel-like structures on bilayer membranes [96]. 
We have demonstrated that these amyloidogenic peptide also cause the elevations in $\left[\mathrm{Ca}^{2+}\right]_{\mathrm{i}}$ as well as $\mathrm{A} \beta \mathrm{P}$ (Figure 3(a)). A marked increase in $\left[\mathrm{Ca}^{2+}\right]_{\mathrm{i}}$ was caused by PrP106-126 (line $(A))$, human amylin (line $(C))$, NAC (line $(E))$ and $\mathrm{A} \beta \mathrm{P}(1-40)$ (Figure $2(\mathrm{a})$, line $(A))$ or pore-forming antimicrobial peptide magainin 2 (line $(F)$ ). However, control peptides such as peptide with random sequence of PrP106-126 (scramble PrP106-126) (line (B)) and rat amylin (line $(D)$ ) caused no remarkable changes. Furthermore, PrP106-126 and human amylin, as well as $\mathrm{A} \beta \mathrm{P}(1-40)$, cause disruption of liposome membranes and induce dye release (Figure 3(b)).

These diseases are included in "conformational disease" (protein misfolding disease) - the conformational change of amyloidogenic proteins is suggested to be an important determinant of its toxicity and, consequently, the development of the disease [97]. The disease-related amyloidogenic proteins exhibit similarities in the formation of $\beta$-pleated sheet structures, abnormal deposition as amyloid fibrils in the tissues, and introduction of apoptotic degeneration. As shown in Table 1, these amyloidogenic proteins exhibit similarities in the direct incorporation into membranes, formation of calcium-permeable ion channels, and induction of abnormal elevation of $\left[\mathrm{Ca}^{2+}\right]_{\mathrm{i}}$. It is strongly suggested that disruption of calcium homeostasis via unregulated amyloid channels formed by these disease-related proteins may be the molecular basis of neurotoxicity of these diseases.

\section{Role of Membrane Lipids in the Formation of Amyloid Channels}

It is widely accepted that the direct incorporation of peptides into membranes and consequent channel formation is strongly affected by the membrane lipid composition, particularly the net charges of membrane surfaces and membrane fluidity. Several A $\beta$ P residues (such as $\mathrm{Arg}^{5}$, $\mathrm{Lys}^{16}$, and $\mathrm{Lys}^{28}$ ) have a positive charge at neutral $\mathrm{pH}$, and therefore, $\mathrm{A} \beta \mathrm{P}$ has an affinity for negatively charged phospholipids, such as phosphatidylserine (PS) or phosphatidylglycerol (PG), but not for neutral phospholipids, such as phosphatidylcholine (PC) [98]. However, membrane phospholipid distribution is asymmetrical in mammals: neutral lipids (PC, etc.) usually exist on the outer surfaces of plasma membranes, whereas negatively charged phospholipids (PS, etc.) exist in the inner surfaces of the membranes. Thus, the binding of $\mathrm{A} \beta \mathrm{P}$ to neuronal membrane surface may seldom occur in normal and young brains.

Further influencing the binding of $\mathrm{A} \beta \mathrm{P}$ to membranes are gangliosides-sialic-acid-bearing glycophospholipids. Both APP and A $\beta P$ are localized in detergentinsoluble, cholesterol-, sphingomyelin-, and ganglioside-rich lipid microdomains, termed rafts [99]. Yanagisawa et al. first demonstrated the existence of membrane-bound $\mathrm{A} \beta \mathrm{P}$ tightly bound to GM1 gangliosides in the brains of $\mathrm{AD}$ patients [100]. A $\beta$ P binds to GM1 gangliosides in raft-like membranes in vitro, and GM1-bound A $\beta$ P behave as a "seed" and accelerate the oligomerization of $\mathrm{A} \beta \mathrm{P}$ [101]. Numerous studies have indicated the implication of gangliosides in the oligomerization and the binding to the membrane of $\mathrm{A} \beta \mathrm{P}$ [102-104].

We have observed the deposition of $\mathrm{A} \beta \mathrm{P}(1-40)$ on ganglioside (GM1)/phospholipid (dipalmitoil phosphatidyl choline; DPPC) monolayers by AFM imaging (Figure 4). GM1-DPPC membranes exhibit distinctive, island-like GM1 domains embedded in the DPPC matrix $[105,106]$. Aged $\mathrm{A} \beta \mathrm{P}(1-40)$ deposited and tightly bound to the membrane surfaces and exhibited the damaged structures of membranes, meanwhile freshly prepared $\mathrm{A} \beta \mathrm{P}$ showed few changes.

We have previously demonstrated that $\mathrm{A} \beta \mathrm{P}$ causes a marked increase in $\left[\mathrm{Ca}^{2+}\right]_{\mathrm{i}}$ in a large proportion of long-term (30-35 days in vitro; DIV) cultured hippocampal neurons. However, few or no changes were observed in $\left[\mathrm{Ca}^{2+}\right]_{\mathrm{i}}$ in short-term (8 DIV) cultures (Figure 5(a)) [107]. After several days of exposure to sublethal levels of $\mathrm{A} \beta \mathrm{P}(1-40)$ to long-term cultured neurons, $\mathrm{A} \beta \mathrm{P}$ binds to some restricted hippocampal neurons and exhibits dotlike depositions on the somata and dendrites. Meanwhile, there is no detectable $\mathrm{A} \beta \mathrm{P}$ deposition on the surfaces of neighboring neurons, despite the morphological similarities of these neurons (Figure 5(b)). Malchiodi-Albedi et al. found that lipid rafts increased during the maturation of culture periods of primary cultured rat hippocampal neurons [108]. They demonstrated that Calcitonin, an amyloidogenic peptide, causes $\left[\mathrm{Ca}^{2+}\right]_{\mathrm{i}}$ changes in mature raft-containing neurons, but not in immature cultured neurons. Williamson et al. found that $\mathrm{A} \beta \mathrm{P}$ was not uniformly distributed over the neuronal processes, and was colocalized with GM1 ganglioside [109]. These features are consistent with our results, and it is possible that gangliosides in lipid rafts may regulate the binding of $\mathrm{A} \beta \mathrm{P}$ into membranes and its neurotoxicity.

It is widely accepted that cholesterol enhances membrane stiffness, decreases membrane fluidity, and inhibits pore formation by pore-forming peptides [110]. Lin and Kagan found that cholesterol inhibits channel formation by $\mathrm{A} \beta \mathrm{P}$ [111]. Cholesterol blocks $\mathrm{A} \beta \mathrm{P}$-induced elevations in $\left[\mathrm{Ca}^{2+}\right]_{i}[41,72]$, aggregation of $\mathrm{A} \beta \mathrm{P}$-containing liposomes $[112]$, and $A \beta P$ cytotoxicity $[112,113]$. Moreover, cholesterol attenuates $\mathrm{A} \beta \mathrm{P}$-induced membrane-disordering effects and calcium increase [114]. Considering that apolipoprotein E, involved in cholesterol transport and metabolism, is present in the senile plaques and NFTs in AD brains and its polymorphism is a risk factor of $\mathrm{AD}$ [115], the implication of cholesterol in $\mathrm{AD}$ pathogenesis is crucial.

To determine the implications of membrane properties in the formation of amyloid channels, we tested the effects of several lipophilic substances, which modulate membrane properties, on $\mathrm{A} \beta \mathrm{P}$-induced $\left[\mathrm{Ca}^{2+}\right]_{\mathrm{i}}$ elevations $[74,107]$. Phloretin, a plant-derived flavonoid, decreases membrane dipole potential, and inhibits the electrostatic interaction between $\mathrm{A} \beta \mathrm{P}$ and membrane lipids, and attenuates $\mathrm{A} \beta \mathrm{P}$ induced neurotoxicity [116]. Meanwhile, 6-ketocholestanol increases the magnitude of the membrane dipole potential and decreases membrane fluidity [117]. Figure 6 shows that the preadministration of phloretin and cholesterol markedly inhibited $A \beta P$-induced $\left[\mathrm{Ca}^{2+}\right]_{\mathrm{i}}$ elevations; meanwhile, 6ketocholestanol did not cause significant changes, despite the 
(A)

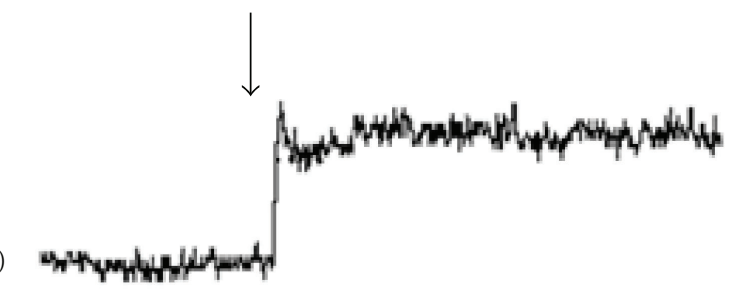

(B)

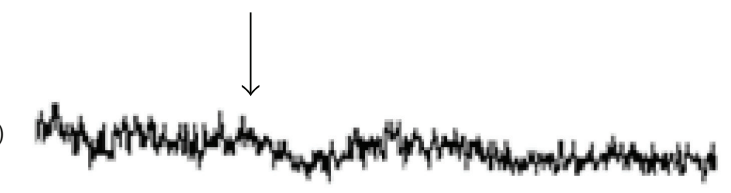

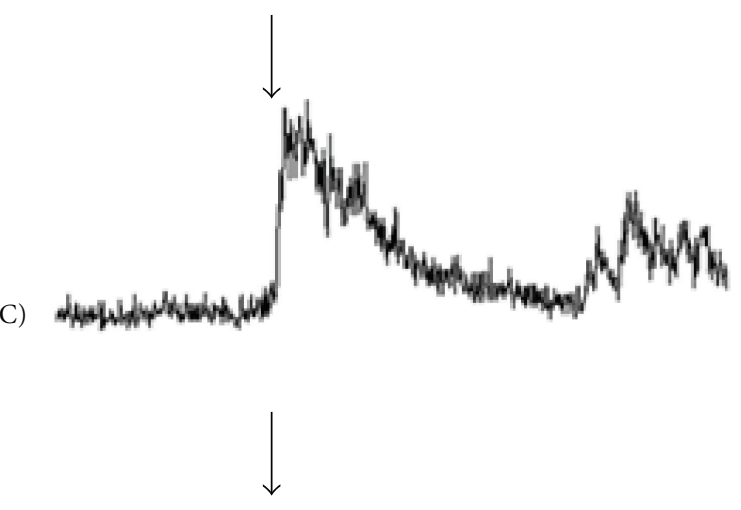

(D)

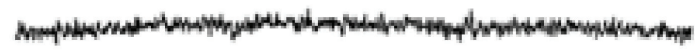

(E)

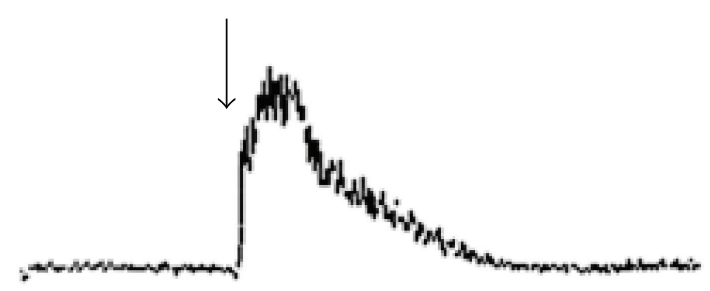

(F)

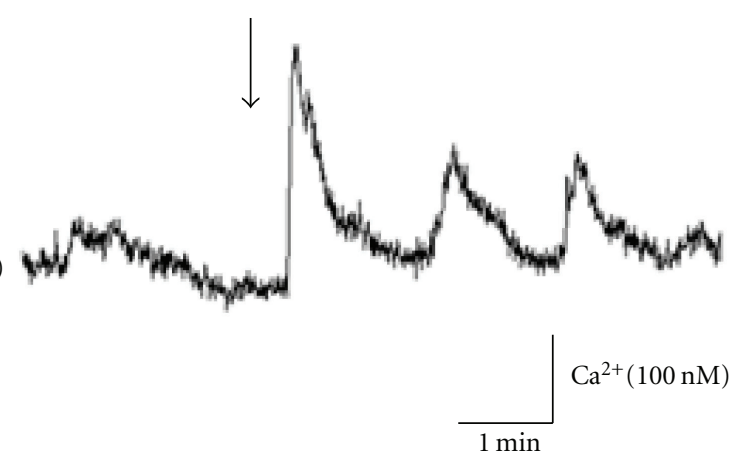

(a)

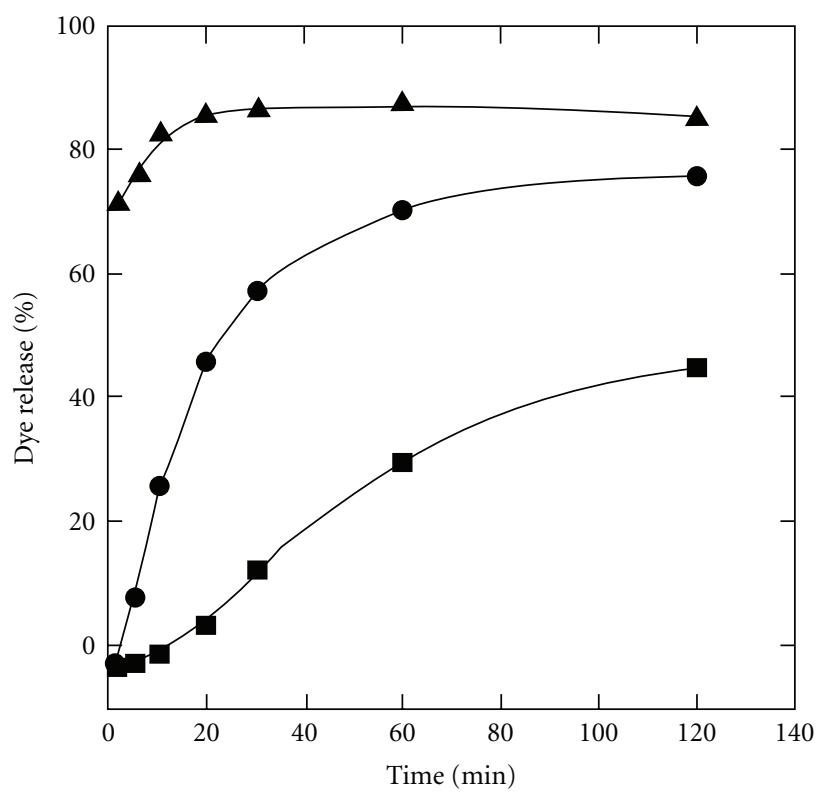

(b)

FIGURE 3: Effects of amyloidogenic proteins on membrane disruption and $\left[\mathrm{Ca}^{2+}\right]_{\mathrm{i}}$ elevations. (a) Effects of amyloidogenic proteins and their analogues on $\left[\mathrm{Ca}^{2+}\right]_{\mathrm{i}}$. Typical time course of $\left[\mathrm{Ca}^{2+}\right]_{\mathrm{i}}$ prior to $2 \mathrm{~min}$ and after $3 \mathrm{~min}$ of the application of the peptide is depicted. Concentration is $10 \mu \mathrm{M}$ for all peptides used. (A) PrP106-126; (B) scramble PrP106-126; (C) human amylin; (D) rat amylin; (E) NAC; (F) magainin 2. The arrow indicates the time of peptide addition. (b) Membrane disruption by amyloidogenic peptides. A $\beta \mathrm{P}(1-40)$ (closed circle), PrP106-126 (closed square), and human amylin (open circle) (each $10 \mu \mathrm{M}$ ) were added to negatively charged liposomes containing carboxyfluorescein. The ratio of DPPC (dipalmitoil phosphatidyl choline) : CHOL (cholesterol) : DPPG (dipalmitoil phosphatidyl glycerol) in the liposome was $3: 4: 3$. The temporal changes of the fluorescence intensity were monitored. The ratio of the released fluorescent dye (carboxy fluoresein; $\mathrm{CF})$ compared to the total amount of CF was described as the percentage of membrane disruption. 

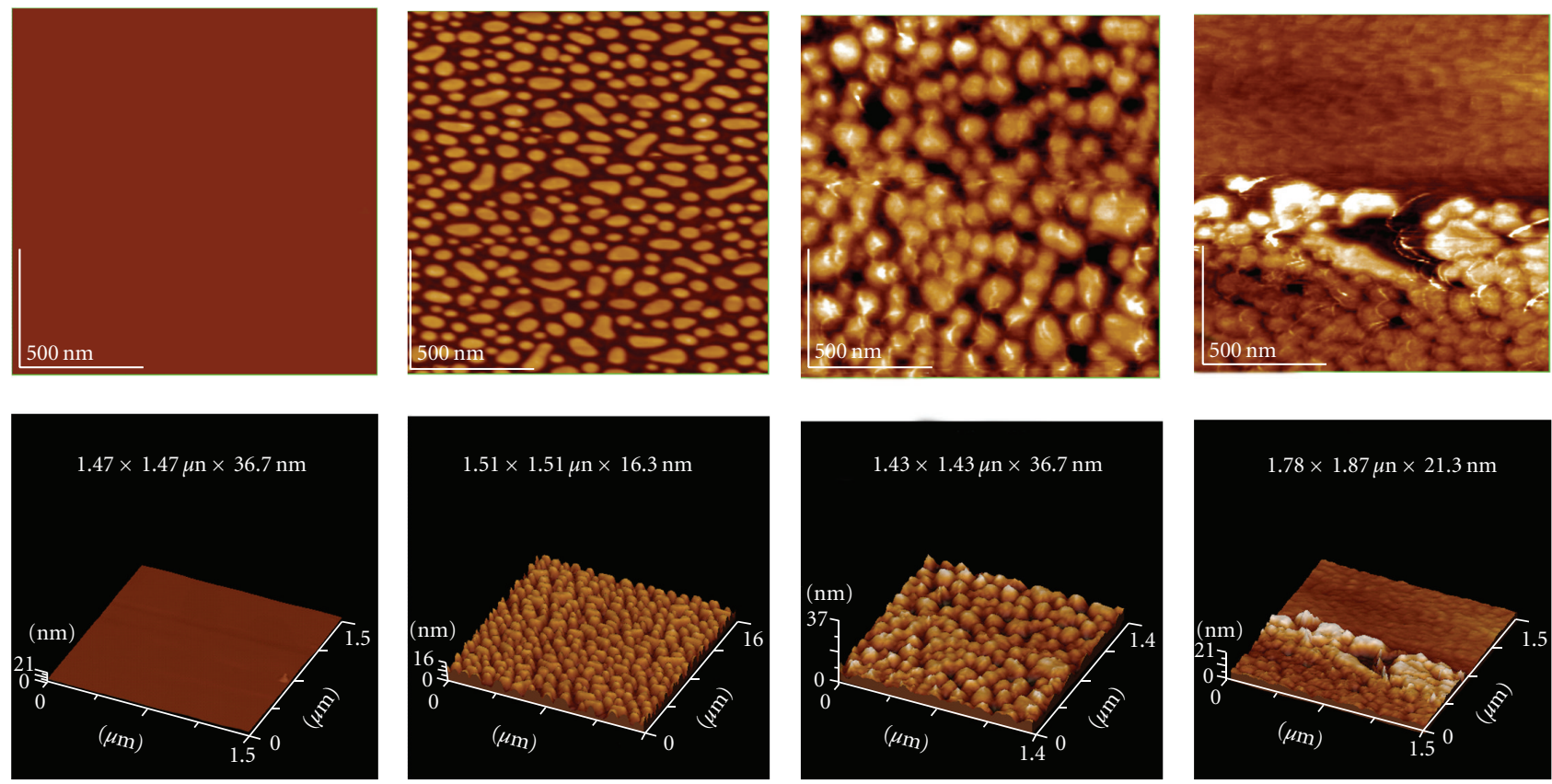

(a)

(b)

(c)

(d)

Figure 4: AFM images of $\mathrm{A} \beta \mathrm{P}(1-40)$ on monolayer membranes. Lipid monolayer membranes composed by DPPC (a) or ganglioside GM1-DPPC (dipalmitoil phosphatidyl choline) (b) (d) were prepared by bath sonication and reconstitution on mica plates. The ratio of GM1:DPPC was $8: 2$. AFM images were obtained after the exposure to freshly prepared $\mathrm{A} \beta \mathrm{P}(1-40)(\mathrm{c})$ or aged $\mathrm{A} \beta \mathrm{P}(1-40)(\mathrm{d})$. Scale area: $1.5 \times 1.5 \mu \mathrm{m}$.

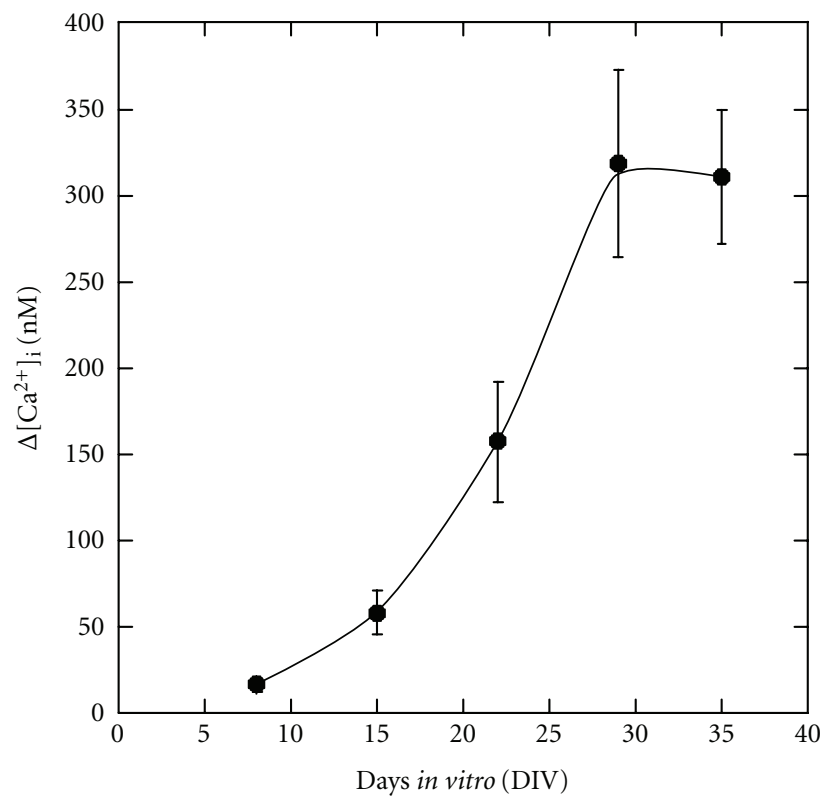

(a)

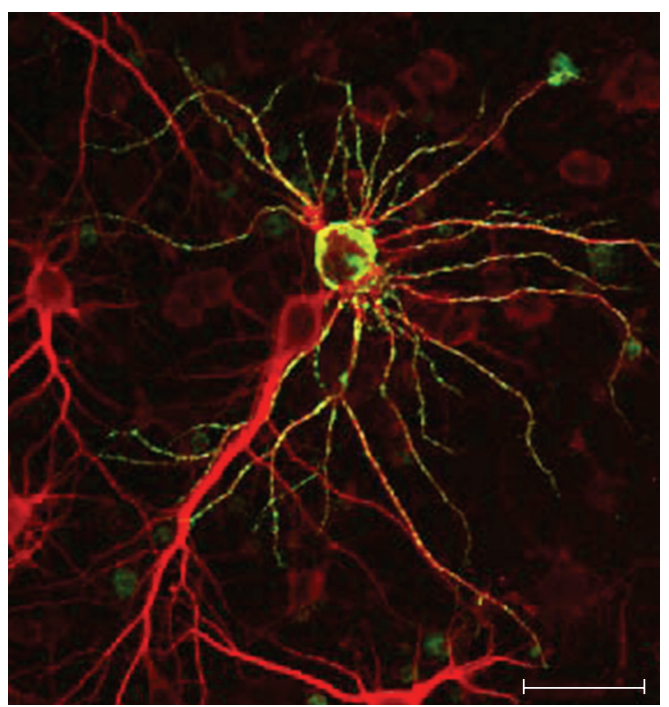

(b)

Figure 5: (a) Maturation-dependent increase in A $\beta$ P-induced $\left[\mathrm{Ca}^{2+}\right]_{\mathrm{i}}$ changes in primary cultured neurons. (b) Heterogeneous affinity of $\mathrm{A} \beta \mathrm{P}$ to mature cultured hippocampal neurons. Long-term cultured rat hippocampal neurons were exposed to $1 \mu \mathrm{M}$ of $\mathrm{A} \beta \mathrm{P}(1-40)$ at $29 \mathrm{DIV}$ and fixed after 4 days. Neurons were double immunostained by anti-MAP2 antibody (Texas Red, red) and anti-A $\beta$ P antibody (FITC, green), and observed by Laser confocal microscopy. Scale bar represents $50 \mu \mathrm{m}$. (modified from [100]). 
TABLE 1: Characteristics of amyloidogenic proteins and the related peptides.

\begin{tabular}{|c|c|c|c|c|c|}
\hline Disease & $\begin{array}{l}\text { Amyloidogenic protein or its fragment peptide and } \\
\text { the primary sequence }\end{array}$ & $\begin{array}{c}\beta \text {-sheet } \\
\text { formation }\end{array}$ & Cytotoxicity & $\begin{array}{l}\text { Channel } \\
\text { formation }\end{array}$ & $\begin{array}{c}{\left[\mathrm{Ca}^{2+}\right]} \\
\text { rise }\end{array}$ \\
\hline \multirow{10}{*}{ Alzheimer's disease } & $A \beta P(1-40)$ & & & & \\
\hline & DAEFRHDSGYEVHHQKLVFFAE & + & + & + & + \\
\hline & DVGSNKGAIIGLMVGGVV & r & & & \\
\hline & $A \beta P(40-1)$ & & & & \\
\hline & VVGGVMLGIIAGKNSGVDEAFFV & - & - & - & - \\
\hline & LKQHHVEYGSDHRFEAD & & & & \\
\hline & $A \beta P(25-35)$ & & & & \\
\hline & DVGSNKGAII & + & + & + & + \\
\hline & $A \beta P(1-42)$ & & & & \\
\hline & $\begin{array}{l}\text { DAEFRHDSGYEVHHQKLVFFAEDV } \\
\text { GSNKGAIIGLMVGGVVIA }\end{array}$ & + & + & + & + \\
\hline \multirow{4}{*}{ Prion disease } & PrP106-126 (prion protein fragment) & & & & \\
\hline & KTNMKHMAGAAAAGAVVGGLG & + & + & + & + \\
\hline & Scramble PrP106-126 & & & & \\
\hline & NGAKALMGGHGATKVMVGAAA & - & - & - & - \\
\hline \multirow{2}{*}{$\begin{array}{l}\text { Parkinson's disease } \\
\text { (DLB; diseases with } \\
\text { Lewy bodies) }\end{array}$} & $\alpha$-synuclein NAC (a fragment of $\alpha$-synuclein) & & & & \\
\hline & $\begin{array}{l}\text { EQVTNVGGAVVTGVTAVAQKTVEGAGSIAA- } \\
\text { ATGFV }\end{array}$ & + & + & + & + \\
\hline \multirow{2}{*}{$\begin{array}{l}\text { Triplet-repeat } \\
\text { disease }\end{array}$} & Polyglutamine & & & & \\
\hline & QQQQQQQQ— & + & + & + & n.d. \\
\hline \multirow{4}{*}{ Diabetes mellitus } & Human amylin & & & & \\
\hline & $\begin{array}{l}\text { KCNTATCATQRLANFLVHSSNNFGAILSST- } \\
\text { NVGSNTY }\end{array}$ & + & + & + & + \\
\hline & Rat amylin & & & & \\
\hline & $\begin{array}{l}\text { KCNTATCATQRLANFLVRSSNNLGPVLPPT- } \\
\text { NVGSNTY }\end{array}$ & - & - & - & - \\
\hline \multirow{2}{*}{$\begin{array}{l}\text { Medullary carcinoma } \\
\text { of the thyroid }\end{array}$} & Calcitonin & & & & \\
\hline & $\begin{array}{l}\text { CGNLSTCMLGTYTQDFNKFHTFPQTAIGVG- } \\
\text { AP }\end{array}$ & + & + & + & + \\
\hline
\end{tabular}

n.d.: not determined.

structural similarity to cholesterol. Therefore, as expected from other findings, the net charges of membrane surfaces and the membrane fluidity play crucial roles in the elevations of $\left[\mathrm{Ca}^{2+}\right]_{\mathrm{i}}$ caused by $\mathrm{A} \beta \mathrm{P}$.

Furthermore, numerous studies have demonstrated that gangliosides and cholesterol are implicated in the channel formation of other amyloidogenic proteins. Lipid rafts are considered to be the compartment where the conformational change of PrP occurs [118]. Gangliosides influence the $\beta$-sheet formation of PrP106-126 [119] and human amylin [120], or the channel formation of $\alpha$-synuclein [121]. Cholesterol also inhibits channel formation by human amylin [122].

\section{Possible Candidate for the Treatment of AD}

The search for protective agents against $\mathrm{A} \beta \mathrm{P}$ neurotoxicity is of great importance. Such agents include inhibitors of $\mathrm{A} \beta \mathrm{P}$ oligomerization, inhibitors of BACE or $\gamma$-secretase, $\mathrm{A} \beta \mathrm{P}$ vaccines, and chelators of trace metals; all have been proposed to be effective in the treatment of AD.
Here, we have focused on substances that inhibit the formation of amyloid channels. As discussed, the elevation of $\left[\mathrm{Ca}^{2+}\right]_{\mathrm{i}}$ by permeation through amyloid channels is considered to be the primary event of $\mathrm{A} \beta \mathrm{P}$ neurotoxicity; therefore, such compounds could serve as the seed of new effective drugs with fewer adverse effects.

$\mathrm{Zn}^{2+}$ ion, which is abundant in vesicles of presynaptic terminals and is secreted into synaptic clefts with neuronal excitation, inhibits the currents induced by amyloid channels $[52,54,70] . \mathrm{Zn}^{2+}$ binds to His residues of $\mathrm{A} \beta \mathrm{P}$ : Arispe et al. found that histidine-related peptide derivatives such as HisHis or polyhistidine are effective in the inhibition of amyloid channels, the attenuation of $\mathrm{A} \beta \mathrm{P}$-induced $\left[\mathrm{Ca}^{2+}\right]_{\mathrm{i}}$ changes, and the protection of neurons from $\mathrm{A} \beta \mathrm{P}$ toxicity [123, 124]. They developed several small amphiphilic pyridinium derivatives which inhibit formation of $\mathrm{A} \beta \mathrm{P}$ channels and its neurotoxicity $[8,125]$.

In line with the search for protective agents, we have screened compounds, which influence membrane properties and inhibit formations of amyloid channels, by observing the $\mathrm{A} \beta \mathrm{P}$-induced $\mathrm{Ca}^{2+}$ influx. Among those tested, we 


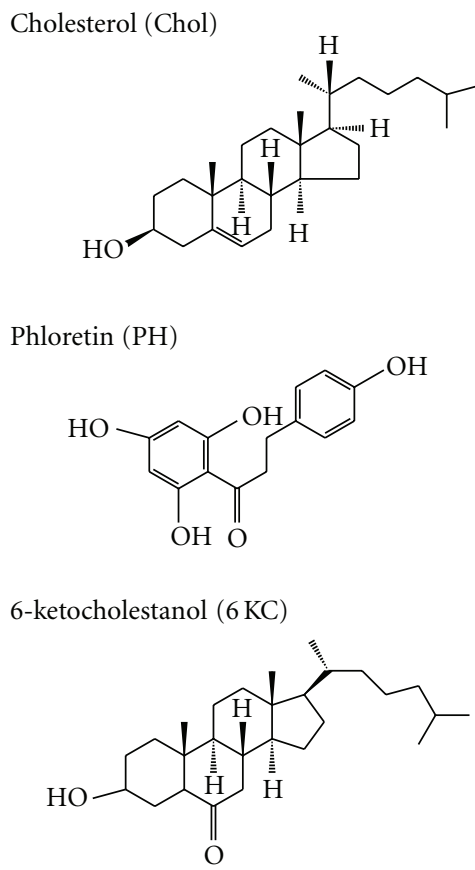

(a)

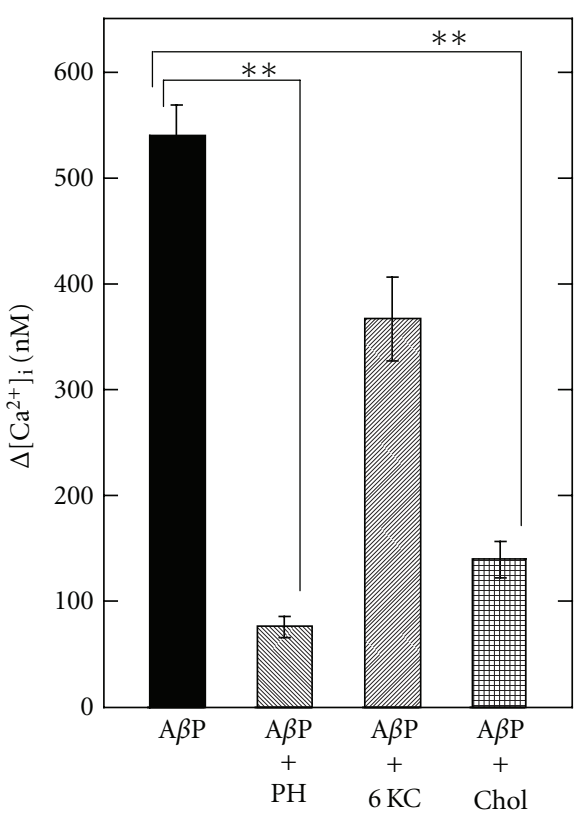

(b)

FIGURE 6: Effect of membrane charges and fluidity on $\mathrm{A} \beta \mathrm{P}$-induced $\left[\mathrm{Ca}^{2+}\right]_{\mathrm{i}}$ rise. The solutions of phloretin $(\mathrm{PH}), 6-\mathrm{ketocholestanol}(\mathrm{KC})$, and cholesterol (Chol) were preadministrated on GT1-7 cells; and A $\beta$ P-induced $\left[\mathrm{Ca}^{2+}\right]_{\mathrm{i}}$ rise was analyzed. Data are mean \pm S.E.M., $n=250$, ${ }^{* *} P<.001$. (modified from [67]).

found that several lipophilic substances, such as $17 \beta$ estradiol, $17 \alpha$-estradiol, and neurosteroids (including dehydroepiandrosterone [DHEA], DHEA sulfate [DHEA-S], and pregnenolone) significantly inhibit A $\beta \mathrm{P}$-induced $\left[\mathrm{Ca}^{2+}\right]_{\mathrm{i}}$ elevation $[74,107] .17 \beta$-estradiol, a female hormone, is neuroprotective and affects membrane fluidity [126]. Considering that both $17 \beta$-estradiol and $17 \alpha$-estradiol inhibit $\mathrm{A} \beta \mathrm{P}-$ induced $\left[\mathrm{Ca}^{2+}\right]_{\mathrm{i}}$ elevation, the inhibition may not depend on their genomic actions but on their membrane-modifying effects. Neurosteroids are steroid hormones synthesized de novo in the central nervous system from cholesterol or from peripheral steroid precursors [127]. Several lines of evidence suggest that neurosteroids modulate various functions of the brain and exhibit neuroprotective activities [128]. Considering that concentrations of plasma DHEA are reduced in $\mathrm{AD}$ patients [129], the implication of neurosteroids in the pathogenesis of $\mathrm{AD}$ may be important.

\section{Amyloid Channel Hypothesis}

Based on the results of our studies, together with those of other studies, we propose the following hypothetical scheme: that unregulated calcium influx via amyloid channels may underlie the molecular mechanism of $\mathrm{A} \beta \mathrm{P}$ neurotoxicity and the pathogenesis of $\mathrm{AD}$ (Figure 7).

$\mathrm{A} \beta \mathrm{Ps}$ are normally secreted from APP, which exists in the synapse, into the cerebrospinal fluid or synaptic clefts. Secreted $A \beta$ Ps are degraded proteolytically by proteases, such as neprilysin [130], within a short period. However, upregulation of the $\mathrm{A} \beta \mathrm{P}$ secretion from $\mathrm{APP}$, or an increased ratio of $\mathrm{A} \beta \mathrm{P}(1-42)$ to $\mathrm{A} \beta \mathrm{P}(1-40)$ may render $\mathrm{A} \beta \mathrm{Ps}$ liable to be retained in the brain. Mutations of APP or presenilin gene promote this process. The binding of $\mathrm{A} \beta \mathrm{P}$ to neuronal membranes is the important determinant for its neurotoxicity. Since $\mathrm{A} \beta \mathrm{P}$ seldom binds to normal neuronal membranes with neutral phospholipids such as PC usually existing on the outer surfaces of plasma membranes, it would be less likely to occur in the brains of normal and young subjects. However, when the asymmetrical distribution is disrupted by apoptotic conditions or aging and negatively charged phospholipids such as PS appear on the outer membrane surfaces, A $\beta$ Ps can bind to membrane surfaces (Figure 7(a)). Furthermore, considering that $\mathrm{A} \beta \mathrm{Ps}$ have affinity to PS in inner membrane surfaces, the intraneuronal accumulation of $\mathrm{A} \beta \mathrm{Ps}$ may be more toxic [131]. Gangliosides also contribute to the net charge of the outer membrane surface and to the binding to A $\beta$ Ps (Figure 7(b)). Microcircumstances on the membranes, such as lipid rafts, provide suitable locations which facilitate this process from (A) to (B). After incorporation into the membrane, the conformation of $\mathrm{A} \beta \mathrm{Ps}$ change and the accumulated $\mathrm{A} \beta \mathrm{Ps}$ aggregate on the membranes. The ratio of cholesterol to phospholipids in the membrane may alter membrane fluidity, thereby affecting these processes. Finally, aggregated $\mathrm{A} \beta \mathrm{P}$ oligomers form ion channels leading to the various neurodegenerative processes (Figure $7(\mathrm{C})$ ).

The velocity of channel formation will be regulated by the binding of $\mathrm{A} \beta \mathrm{P}$ on membranes and its concentration. Considering that soluble oligomers are more toxic compared to monomer or fibrils $[26,27,65]$, it is provable that 


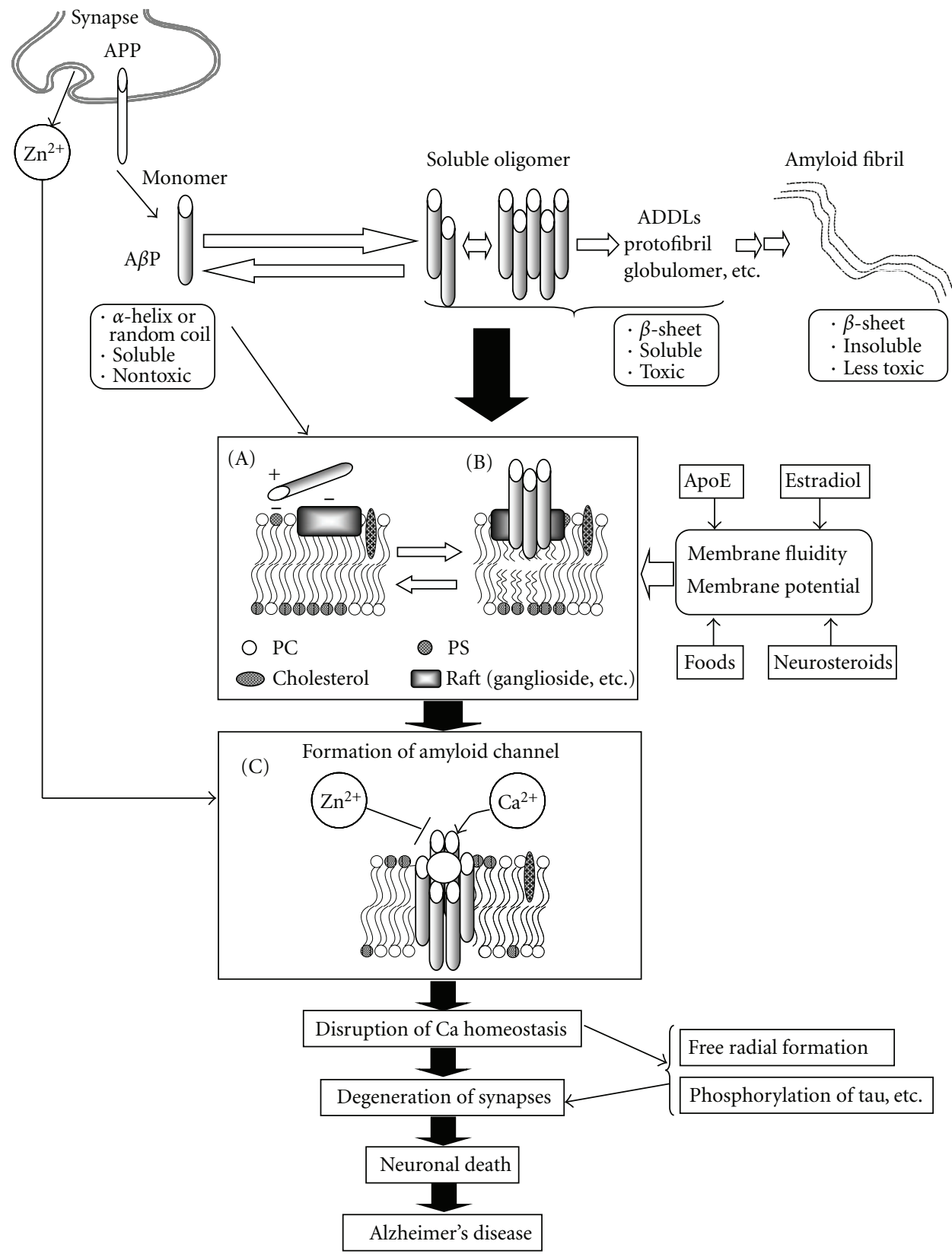

FIGURE 7: Hypothesis concerning amyloid channels and pathogenesis of Alzheimer's disease. A $\beta$ Ps are secreted from APP in synapses, directly incorporated into membranes. The possible hypothetical scheme of the formation of oligomeric amyloid channels is depicted. Details are shown in the text.

$\mathrm{A} \beta \mathrm{P}$ oligomerization in vitro accelerates the velocity from (A) to (B), and enhances the formation of tetrameric or hexameric pores on membranes. Indeed, O’Nuallain et al. demonstrated that $\mathrm{A} \beta \mathrm{P}$ dimers formed toxic protofibrils more rapidly compared to monomer [132]. However, the proposed structures of $\mathrm{A} \beta \mathrm{P}$ channels in membrane mimic conditions are not always similar to the structures formed in the solution such as protofibrils or soluble oligomers. Thus, the conformational changes in membranes may also be significant.

These processes required for channel formation ((A) to (C)) may require a long life span in general and determine the rate of the entire process. Unlike endogenous $\mathrm{Ca}^{2+}$ channels, these $\mathrm{A} \beta \mathrm{P}$ channels are not regulated by usual blockers. Thus, once formed on membranes, a continuous flow of $\left[\mathrm{Ca}^{2+}\right]_{i}$ is initiated.

Disruption of calcium homeostasis triggers several apoptotic pathways and promotes numerous degenerative processes, including free radical formation and tau phosphorylation, thereby accelerating neuronal death. The source of $\mathrm{Ca}^{2+}$ may be from extracellular or intracellular $\mathrm{Ca}^{2+}$ store (ER or mitochondoria). Considering that presenilins are involved in the capacitive calcium entry, in $\mathrm{Ca}^{2+}$ homeostasis in ER or in mitochondoria [46-49] and the implication of ER stress in 
$\mathrm{AD}$ and other neurodegenerative diseases [133], mutations of presenilins may influence these pathways. Free radicals also induce membrane disruption, by which unregulated calcium influx is further amplified. The disruption of calcium homeostasis influences the production and processing of APP. Thus, a vicious spiral of neurodegeneration is initiated. Meanwhile, zinc ions, which are secreted into synaptic clefts in a neuronal activity-dependent manner, inhibit $\mathrm{A} \beta \mathrm{P}$ induced $\mathrm{Ca}^{2+}$ entry, and thus have a protective function in $\mathrm{AD}$.

This hypothesis explains the long delay in AD development; $\mathrm{AD}$ occurs only in senile subjects despite the fact that $\mathrm{A} \beta \mathrm{Ps}$ are also normally secreted in younger or in normal subjects. AD is multifactorial disease. Various environmental factors, such as foods (cholesterol contents) or trace metals, as well as genetic factors will influence these processes and contribute to $\mathrm{AD}$ pathogenesis. The amyloid channel hypothesis could explain effects of environmental factors such as cholesterol and other various aspects of AD pathogenesis and may aid in improving a precise understanding of $\mathrm{AD}$ and in the development of drugs for $\mathrm{AD}$ treatment. Although the findings of channel-like structures in vivo $[66,68]$, it is difficult to determine whether these amyloid channels really exist in the brains of $\mathrm{AD}$ patients. Therefore, further in vivo studies are necessary.

\section{Abbreviations}

AD: Alzheimer's disease,

A $\beta$ P: $\quad$ Alzheimer's $\beta$-amyloid protein

AFM: $\quad$ Atomic force microscopy

AMPA: $\alpha$-amino-3-hydroxy-5-methylisoxazole-4propionic acid

APP: Amyloid precursor protein

D-APV: 2-amino-5-phosphonovalerate

BACE: $\beta$-site APP cleaving enzyme

ER: Endoplasmic reticulum

LTP: Long-term potentiation

NFT: Neurofibrillary tangles

$\left[\mathrm{Ca}^{2+}\right]_{\mathrm{i}}$ : Intracellular calcium levels

NMDA: N-methyl-D-aspartate

ROS: Reactive oxygen species

SDS: Sodium dodecyl sulfate

TTX: Tetrodotoxin.

\section{Acknowledgments}

This work was partially supported by a Grant-in-Aid for Scientific Research from the Ministry of Education, Culture, Sports, Science and Technology of Japan and by a Grant from the Cooperation for Innovative Technology and Advanced Research in Evolutional Area (city area) by the Miyazaki Prefectural Industrial Support Foundation.

\section{References}

[1] D. J. Selkoe, "The molecular pathology of Alzheimer's disease," Neuron, vol. 6, no. 4, pp. 487-498, 1991.
[2] J. Hardy and D. J. Selkoe, "The amyloid hypothesis of Alzheimer's disease: progress and problems on the road to therapeutics," Science, vol. 297, no. 5580, pp. 353-356, 2002.

[3] O. Wirths, G. Multhaup, and T. A. Bayer, "A modified $\beta$ amyloid hypothesis: intraneuronal accumulation of the $\beta$ amyloid peptide - the first step of a fatal cascade," Journal of Neurochemistry, vol. 91, no. 3, pp. 513-520, 2004.

[4] D. H. Small, S. S. Mok, and J. C. Bornstein, "Alzheimer's disease and A $\beta$ toxicity: from top to bottom," Nature Reviews Neuroscience, vol. 2, no. 8, pp. 595-598, 2001.

[5] A. Demuro, I. Parker, and G. E. Stutzmann, "Calcium signaling and amyloid toxicity in Alzheimer disease," Journal of Biological Chemistry, vol. 285, no. 17, pp. 12463-12468, 2010.

[6] C. Supnet and I. Bezprozvanny, "The dysregulation of intracellular calcium in Alzheimer disease," Cell Calcium, vol. 47, no. 2, pp. 183-189, 2010.

[7] S. Camandola and M. P. Mattson, "Aberrant subcellular neuronal calciumregulation in aging and Alzheimer's disease," Biochimica et Biophysica Acta. In press.

[8] N. Arispe, J. C. Diaz, and O. Simakova, "A $\beta$ ion channels. Prospects for treating Alzheimer's disease with $A \beta$ channel blockers," Biochimica et Biophysica Acta, vol. 1768, no. 8, pp. 1952-1965, 2007.

[9] H. A. Lashuel and P. T. Lansbury Jr., "Are amyloid diseases caused by protein aggregates that mimic bacterial poreforming toxins?" Quarterly Reviews of Biophysics, vol. 39, no. 2, pp. 167-201, 2006.

[10] M. Kawahara, M. Negishi-Kato, and Y. Sadakane, "Calcium dyshomeostasis and neurotoxicity of Alzheimer's $\beta$-amyloid protein," Expert Review of Neurotherapeutics, vol. 9, no. 5, pp. 681-693, 2009.

[11] A. Goate, M. C. Chartier-Harlin, M. Mullan et al., "Segregation of a missense mutation in the amyloid precursor protein gene with familial Alzheimer's disease," Nature, vol. 349, no. 6311, pp. 704-706, 1991.

[12] R. Sherrington, E. I. Rogaev, Y. Liang et al., "Cloning of a gene bearing missense mutations in early-onset familial Alzheimer's disease," Nature, vol. 375, no. 6534, pp. 754-760, 1995.

[13] D. J. Selkoe and M. S. Wolfe, "Presenilin: running with scissors in the membrane," Cell, vol. 131, no. 2, pp. 215-221, 2007.

[14] L. Bertram and R. E. Tanzi, "Thirty years of Alzheimer's disease genetics: the implications of systematic meta-analyses," Nature Reviews Neuroscience, vol. 9, no. 10, pp. 768-778, 2008.

[15] B. A. Yankner, L. K. Duffy, and D. A. Kirschner, "Neurotrophic and neurotoxic effects of amyloid $\beta$ protein: reversal by tachykinin neuropeptides," Science, vol. 250, no. 4978, pp. 279-282, 1990.

[16] C. J. Pike, A. J. Walencewicz, C. G. Glabe, and C. W. Cotman, "In vitro aging of $\beta$-amyloid protein causes peptide aggregation and neurotoxicity," Brain Research, vol. 563, no. 1-2, pp. 311-314, 1991.

[17] L. K. Simmons, P. C. May, K. J. Tomaselli et al., "Secondary structure of amyloid $\beta$ peptide correlates with neurotoxic activity in vitro," Molecular Pharmacology, vol. 45, no. 3, pp. 373-379, 1994.

[18] J. T. Jarrett and P. T. Lansbury, "Seeding "one-dimensional crystallization" of amyloid: a pathogenic mechanism in Alzheimer's disease and scrapie?" Cell, vol. 73, no. 6, pp. 1055-1058, 1993. 
[19] D. M. Walsh and D. J. Selkoe, "A $\beta$ oligomers-a decade of discovery," Journal of Neurochemistry, vol. 101, no. 5, pp. 1172-1184, 2007.

[20] C. G. Glabe, "Common mechanisms of amyloid oligomer pathogenesis in degenerative disease," Neurobiology of Aging, vol. 27 , no. 4, pp. 570-575, 2006.

[21] W. L. Klein, W. B. Stine, and D. B. Teplow, "Small assemblies of unmodified amyloid $\beta$-protein are the proximate neurotoxin in Alzheimer's disease," Neurobiology of Aging, vol. 25, no. 5, pp. 569-580, 2004.

[22] D. M. Hartley, D. M. Walsh, C. P. Ye et al., "Protofibrillar intermediates of amyloid $\beta$-protein induce acute electrophysiological changes and progressive neurotoxicity in cortical neurons," Journal of Neuroscience, vol. 19, no. 20, pp. 8876$8884,1999$.

[23] D. M. Walsh, B. P. Tseng, R. E. Rydel, M. B. Podlisny, and D. J. Selkoe, "The oligomerization of amyloid $\beta$-protein begins intracellularly in cells derived from human brain," Biochemistry, vol. 39, no. 35, pp. 10831-10839, 2000.

[24] P. N. Lacor, M. C. Buniel, P. W. Furlow et al., "A $\beta$ oligomerinduced aberrations in synapse composition, shape, and density provide a molecular basis for loss of connectivity in Alzheimer's disease," Journal of Neuroscience, vol. 27, no. 4, pp. 796-807, 2007.

[25] A. Jan, O. Adolfsson, I. Allaman et al., "Aß42 neurotoxicity is mediated by ongoing nucleated polymerization process rather than by discrete Aß42 species," Journal of Biological Chemistry, vol. 286, no. 10, pp. 8585-8596, 2011.

[26] B. Caughey and P. T. Lansbury, "Protofibrils, pores, fibrils, and neurodegeneration: separating the responsible protein aggregates from the innocent bystanders," Annual Review of Neuroscience, vol. 26, pp. 267-298, 2003.

[27] M. Stefani, "Biochemical and biophysical features of both oligomer/fibril and cell membrane in amyloid cytotoxicity," FEBS Journal, vol. 277, no. 22, pp. 4602-4613, 2010.

[28] V. Novitskaya, O. V. Bocharova, I. Bronstein, and I. V. Baskakov, "Amyloid fibrils of mammalian prion protein are highly toxic to cultured cells and primary neurons," Journal of Biological Chemistry, vol. 281, no. 19, pp. 13828-13836, 2006.

[29] M. F. M. Engel, L. Khemtémourian, C. C. Kleijer et al., "Membrane damage by human islet amyloid polypeptide through fibril growth at the membrane," Proceedings of the National Academy of Sciences of the United States of America, vol. 105, no. 16, pp. 6033-6038, 2008.

[30] Z. Xu, R. Paparcone, and M. J. Buehler, “Alzheimer's A $\beta(1-40)$ amyloid fibrils feature size-dependent mechanical properties," Biophysical Journal, vol. 98, no. 10, pp. 20532062, 2010.

[31] R. D. Terry, E. Masliah, D. P. Salmon et al., "Physical basis of cognitive alterations in Alzheimer's disease: synapse loss is the major correlate of cognitive impairment," Annals of Neurology, vol. 30, no. 4, pp. 572-580, 1991.

[32] R. Fukuyama, T. Mizuno, T. Mizuno et al., "Age-dependent change in the levels of $A \beta 40$ and $A \beta 42$ in cerebrospinal fluid from control subjects, and a decrease in the ratio of $\mathrm{A} \beta 42$ to $A \beta 40$ level in cerebrospinal fluid from Alzheimer's disease patients," European Neurology, vol. 43, no. 3, pp. 155-160, 2000.

[33] M. Kawahara, "Role of calcium dyshomeostasis via amyloid channels in the pathogenesis of Alzheimer's disease," Current Pharmaceutical Design, vol. 16, pp. 2779-2789, 2010.

[34] M. Kawahara, "Effects of aluminum on the nervous system and its possible link with neurodegenerative diseases," Journal of Alzheimer's Disease, vol. 8, no. 2, pp. 171-182, 2005.
[35] M. Kato-Negishi, K. Muramoto, M. Kawahara, R. Hosoda, Y. Kuroda, and M. Ichikawa, "Bicuculline induces synapse formation on primary cultured accessory olfactory bulb neurons," European Journal of Neuroscience, vol. 18, no. 6, pp. 1343-1352, 2003.

[36] S. L. Sabo, A. F. Ikin, J. D. Buxbaum, and P. Greengard, “The amyloid precursor protein and its regulatory protein, FE65, in growth cones and synapses in vitro and in vivo," Journal of Neuroscience, vol. 23, no. 13, pp. 5407-5415, 2003.

[37] G. V. W. Johnson, "Tau phosphorylation and proteolysis: insights and perspectives," Journal of Alzheimer's Disease, vol. 9, no. 3, pp. 243-250, 2006.

[38] W. Gordon-Krajcer and B. Gajkowska, "Excitotoxicityinduced expression of amyloid precursor protein ( $\beta$-APP) in the hippocampus and cortex of rat brain. An electronmicroscopy and biochemical study," Folia Neuropathologica, vol. 39, no. 3, pp. 163-173, 2001.

[39] L. Gasparini, M. Racchi, G. Binetti et al., "Peripheral markers in testing pathophysiological hypotheses and diagnosing Alzheimer's disease," FASEB Journal, vol. 12, no. 1, pp. 1734, 1998.

[40] M. P. Mattson, S. W. Barger, B. Cheng, I. Lieberburg, V. L. Smith-Swintosky, and R. E. Rydel, " $\beta$-Amyloid precursor protein metabolites and loss of neuronal $\mathrm{Ca}$ homeostasis in Alzheimer's disease," Trends in Neurosciences, vol. 16, no. 10, pp. 409-414, 1993.

[41] H. Hartmann, A. Eckert, and W. E. Müller, "Disturbances of the neuronal calcium homeostasis in the aging nervous system," Life Sciences, vol. 55, no. 25-26, pp. 2011-2018, 1994.

[42] E. Alberdi, M. V. Sánchez-Gómez, F. Cavaliere et al., "Amyloid $\beta$ oligomers induce Ca dysregulation and neuronal death through activation of ionotropic glutamate receptors," Cell Calcium, vol. 47, no. 3, pp. 264-272, 2010.

[43] H. R. Parri and K. T. Dineley, "Nicotinic acetylcholine receptor interaction with $\beta$-amyloid: molecular, cellular, and physiological consequences," Current Alzheimer Research, vol. 7, no. 1, pp. 27-39, 2010.

[44] J. H. Weiss, C. J. Pike, and C. W. Cotman, " $\mathrm{Ca}^{2+}$ channel blockers attenuate $\beta$-amyloid peptide toxicity to cortical neurons in culture," Journal of Neurochemistry, vol. 62, no. 1, pp. 372-375, 1994.

[45] K. H. Cheung, L. Mei, D. O. D. Mak et al., "Gain-offunction enhancement of IP receptor modal gating by familial Alzheimer's disease-linked presenilin mutants in human cells and mouse neurons," Science Signaling, vol. 3, no. 114, p. ra22, 2010.

[46] H. W. Querfurth and F. M. LaFerla, "Alzheimer's disease," New England Journal of Medicine, vol. 362, no. 4, pp. 329344, 2010.

[47] K. Leuner, S. Hauptmann, R. Abdel-Kader et al., "Mitochondrial dysfunction: the first domino in brain aging and Alzheimer's disease?" Antioxidants and Redox Signaling, vol. 9, no. 10, pp. 1659-1675, 2007.

[48] J. Herms, I. Schneider, I. Dewachter, N. Caluwaerts, H. Kretzschmar, and F. Van Leuven, "Capacitive calcium entry is directly attenuated by mutant presenilin-1, independent of the expression of the amyloid precursor protein," Journal of Biological Chemistry, vol. 278, no. 4, pp. 2484-2489, 2003.

[49] K. N. Green, A. Demuro, Y. Akbari et al., "SERCA pump activity is physiologically regulated by presenilin and regulates amyloid $\beta$ production," Journal of Cell Biology, vol. 181, no. 7, pp. 1107-1116, 2008.

[50] N. Arispe, E. Rojas, and H. B. Pollard, "Alzheimer disease amyloid $\beta$ protein forms calcium channels in bilayer 
membranes: blockade by tromethamine and aluminum," Proceedings of the National Academy of Sciences of the United States of America, vol. 90, no. 2, pp. 567-571, 1993.

[51] N. Arispe, H. B. Pollard, and E. Rojas, "Giant multilevel cation channels formed by Alzheimer disease amyloid $\beta$ protein $[\mathrm{A} \beta \mathrm{P}-(1-40)]$ in bilayer membranes," Proceedings of the National Academy of Sciences of the United States of America, vol. 90, no. 22, pp. 10573-10577, 1993.

[52] N. Arispe, H. B. Pollard, and E. Rojas, " $\mathrm{Zn}^{2+}$ interaction with Alzheimer amyloid $\beta$ protein calcium channels," Proceedings of the National Academy of Sciences of the United States of America, vol. 93, no. 4, pp. 1710-1715, 1996.

[53] T. Mirzabekov, M. C. Lin, W. L. Yuan et al., "Channel formation in planar lipid bilayers by a neurotoxic fragment of the beta-amyloid peptide," Biochemical and Biophysical Research Communications, vol. 202, no. 2, pp. 1142-1148, 1994.

[54] S. K. Rhee, A. P. Quist, and R. Lal, "Amyloid $\beta$ protein-(1-42) forms calcium-permeable, Zn-sensitive channel," Journal of Biological Chemistry, vol. 273, no. 22, pp. 13379-13382, 1998.

[55] S. P. Fraser, Y. H. Suh, Y. H. Chong, and M. B. A. Djamgoz, "Membrane currents induced in Xenopus oocytes by the C-terminal fragment of the $\beta$-amyloid precursor protein," Journal of Neurochemistry, vol. 66, no. 5, pp. 2034-2040, 1996.

[56] S. R. Durell, H. R. Guy, N. Arispe, E. Rojas, and H. B. Pollard, "Theoretical models of the ion channel structure of amyloid $\beta$-protein," Biophysical Journal, vol. 67, no. 6, pp. 2137-2145, 1994.

[57] B. Strodel, J. W. L. Lee, C. S. Whittleston, and D. J. Wales, "Transmembrane structures for Alzheimer's A $\beta 1-42$ oligomers," Journal of the American Chemical Society, vol. 132, no. 38, pp. 13300-13312, 2010.

[58] H. Lin, R. Bhatia, and R. Lal, "Amyloid $\beta$ protein forms ion channels: implications for Alzheimer's disease pathophysiology," FASEB Journal, vol. 15, no. 13, pp. 2433-2444, 2001.

[59] H. Jang, F. T. Arce, S. Ramachandran, R. Capone, R. Lal, and R. Nussinov, " $\beta$-barrel topology of Alzheimer's $\beta$-Amyloid ion channels," Journal of Molecular Biology, vol. 404, no. 5, pp. 917-934, 2010.

[60] H. Jang, J. Zheng, and R. Nussinov, "Models of betaamyloid ion channels in the membrane suggest that channel formation in the bilayer is a dynamic process," Biophysical Journal, vol. 93, pp. 1938-1949, 2007.

[61] G. P. Eckert, W. G. Wood, and W. E. Müller, "Membrane disordering effects of beta-amyloid peptides," Sub-cellular biochemistry, vol. 38, pp. 319-337, 2005.

[62] M. P. Mattson, J. G. Begley, R. J. Mark, and K. Furukawa, "A $\beta 25-35$ induces rapid lysis of red blood cells: contrast with a $\beta 1-42$ and examination of underlying mechanisms," Brain Research, vol. 771, no. 1, pp. 147-153, 1997.

[63] J. McLaurin and A. Chakrabartty, "Membrane disruption by Alzheimer $\beta$-amyloid peptides mediated through specific binding to either phospholipids or gangliosides. Implications for neurotoxicity," Journal of Biological Chemistry, vol. 271, no. 43, pp. 26482-26489, 1996.

[64] E. M. Blanc, M. Toborek, R. J. Mark, B. Hennig, and M. P. Mattson, "Amyloid $\beta$-peptide induces cell monolayer albumin permeability, impairs glucose transport, and induces apoptosis in vascular endothelial cells," Journal of Neurochemistry, vol. 68, no. 5, pp. 1870-1881, 1997.

[65] A. Demuro, E. Mina, R. Kayed, S. C. Milton, I. Parker, and C. G. Glabe, "Calcium dysregulation and membrane disruption as a ubiquitous neurotoxic mechanism of soluble amyloid oligomers," Journal of Biological Chemistry, vol. 280, pp. 17294-17300, 2005.

[66] S. Inoue, "In situ $\mathrm{A} \beta$ pores in $\mathrm{AD}$ brain are cylindrical assembly of A $\beta$ protofilaments," Amyloid, vol. 15, no. 4, pp. 223-233, 2008

[67] R. Kayed, A. Pensalfini, L. Margol et al., "Annular protofibrils area structurally and functionally distinct type of amyloid oligomer," Journal of Biological Chemistry, vol. 284, no. 7, pp. 4230-4237, 2009.

[68] H. Kokubo, R. Kayed, C. G. Glabe et al., "Amyloid ß annular protofibrils in cell processes and synapses accumulate with aging and Alzheimer-associated genetic modification," International Journal of Alzheimer's Disease, vol. 2009, Article ID 689285, 7 pages, 2009.

[69] P. L. Mellon, J. J. Windle, P. C. Goldsmith, C. A. Padula, J. L. Roberts, and R. I. Weiner, "Immortalization of hypothalamic GnRH neurons by genetically targeted tumorigenesis," Neuron, vol. 5, no. 1, pp. 1-10, 1990.

[70] M. Kawahara, N. Arispe, Y. Kuroda, and E. Rojas, "Alzheimer's disease amyloid $\beta$-protein forms $\mathrm{Zn}^{2+}$-sensitive, cation- selective channels across excised membrane patches from hypothalamic neurons," Biophysical Journal, vol. 73, no. 1, pp. 67-75, 1997.

[71] F. J. Sepulveda, J. Parodi, R. W. Peoples, C. Opazo, and L. G. Aguayo, "Synaptotoxicity of Alzheimer $B$ amyloid can be explained by its membrane perforating property," PLoS One, vol. 27, article e11820, 2010.

[72] M. Kawahara, N. Arispe, Y. Kuroda, and E. Rojas, "Alzheimer's ß-amyloid, human islet amylin and prion protein fragment evoke intracellular free-calcium elevations by a common mechanism in a hypothalamic GnRH neuronal cell-line," Journal of Biological Chemistry, vol. 275, pp. 1407714083, 2000.

[73] M. Kawahara and Y. Kuroda, "Molecular mechanism of neurodegeneration induced by Alzheimer's $\beta$-amyloid protein: channel formation and disruption of calcium homeostasis," Brain Research Bulletin, vol. 53, no. 4, pp. 389-397, 2000.

[74] M. Kawahara and Y. Kuroda, "Intracellular calcium changes in neuronal cells induced by Alzheimer's $\beta$-amyloid protein are blocked by estradiol and cholesterol," Cellular and Molecular Neurobiology, vol. 21, no. 1, pp. 1-13, 2001.

[75] O. Simakova and N. J. Arispe, "The cell-selective neurotoxicity of the Alzheimer's $\mathrm{A} \beta$ peptide is determined by surface phosphatidylserine and cytosolic ATP levels. Membrane binding is required for $\mathrm{A} \beta$ toxicity," Journal of Neuroscience, vol. 27, no. 50, pp. 13719-13729, 2007.

[76] T. Tomita, M. Watanabe, and T. Yasuda, "Influence of membrane fluidity on the assembly of Staphylococcus aureus $\alpha$-toxin, a channel-forming protein, in liposome membrane," Journal of Biological Chemistry, vol. 267, no. 19, pp. 1339113397, 1992.

[77] M. Kawahara, "Disruption of calcium homeostasis in the pathogenesis of Alzheimer's disease and other conformational diseases," Curr Alzheimer Res, vol. 1, no. 2, pp. 87-95, 2004.

[78] D. H. Cribbs, C. J. Pike, S. L. Weinstein, P. Velazquez, and C. W. Cotman, "All-D-enantiomers of $\beta$-amyloid exhibit similar biological properties to all-L- $\beta$-amyloids," Journal of Biological Chemistry, vol. 272, no. 11, pp. 7431-7436, 1997.

[79] S. Bhakdi and J. Tranum-Jensen, "Alpha-toxin of Staphylococcus aureus," Microbiological Reviews, vol. 55, no. 4, pp. 733751, 1991.

[80] Y. Imura, N. Choda, and K. Matsuzaki, "Magainin 2 in action: distinct modes of membrane permeabilization in 
living bacterial and mammalian cells," Biophysical Journal, vol. 95, no. 12, pp. 5757-5765, 2008.

[81] B. Bechinger and K. Lohner, "Detergent-like actions of linear amphipathic cationic antimicrobial peptides," Biochimica et Biophysica Acta, vol. 1758, no. 9, pp. 1529-1539, 2006.

[82] S. J. Soscia, J. E. Kirby, K. J. Washicosky et al., "The Alzheimer's disease-associated amyloid $\beta$-protein is an antimicrobial peptide," PLOS ONE, vol. 5, no. 3, article e9505, 2010.

[83] S. B. Prusiner, "Prions," Proceedings of the National Academy of Sciences of the United States of America, vol. 95, no. 23, pp. 13363-13383, 1998.

[84] G. Forloni, N. Angeretti, R. Chiesa et al., "Neurotoxicity of a prion protein fragment," Nature, vol. 362 , no. 6420, pp. 543546, 1993.

[85] M. C. Lin, T. Mirzabekov, and B. L. Kagan, "Channel formation by a neurotoxic prion protein fragment," Journal of Biological Chemistry, vol. 272, no. 1, pp. 44-47, 1997.

[86] J. I. Kourie and A. Culverson, "Prion peptide fragment $\operatorname{PrP}$ [106-126] forms distinct cation channel types," Journal of Neuroscience Research, vol. 62, no. 1, pp. 120-133, 2000.

[87] B. Kaplan, V. Ratner, and E. Haas, " $\alpha$-synuclein: its biological function and role in neurodegenerative diseases," Journal of Molecular Neuroscience, vol. 20, no. 2, pp. 83-92, 2003.

[88] O. M. El-Agnaf and G. B. Irvine, "Aggregation and neurotoxicity of $\alpha$-synuclein and related peptides," Biochemical Society Transactions, vol. 30, no. 4, pp. 559-565, 2002.

[89] H. A. Lashuel, D. Hartley, B. M. Petre, T. Walz, and P. T. Lansbury Jr., "Neurodegenerative disease: amyloid pores from pathogenic mutations," Nature, vol. 418, no. 6895, p. 291, 2002.

[90] H. Ikeda, M. Yamaguchi, S. Sugai, Y. Aze, S. Narumiya, and A. Kakizuka, "Expanded polyglutamine in the Machado-Joseph disease protein induces cell death in vitro and in vivo," Nature Genetics, vol. 13, no. 2, pp. 196-202, 1996.

[91] Y. Hirakura, R. Azimov, R. Azimova, and B. L. Kagan, "Polyglutamine-induced ion channels: a possible mechanism for the neurotoxicity of huntington and other CAG repeat diseases," Journal of Neuroscience Research, vol. 60, no. 4, pp. 490-494, 2000.

[92] E. T. A. S. Jaikaran and A. Clark, "Islet amyloid and type 2 diabetes: from molecular misfolding to islet pathophysiology," Biochimica et Biophysica Acta, vol. 1537, no. 3, pp. 179203, 2001.

[93] T. A. Mirzabekov, M. C. Lin, and B. L. Kagan, "Pore formation by the cytotoxic islet amyloid peptide amylin," Journal of Biological Chemistry, vol. 271, no. 4, pp. 19881992, 1996.

[94] S. J. Wimalawansa, "Amylin, calcitonin gene-related peptide, calcitonin, and adrenomedullin: a peptide superfamily," Critical Reviews in Neurobiology, vol. 11, no. 2-3, pp. 167239, 1997.

[95] M. Diociaiuti, L. Z. Polzi, L. Valvo, F. Malchiodi-Albedi, C. Bombelli, and M. C. Gaudiano, "Calcitonin forms oligomeric pore-like structures in lipid membranes," Biophysical Journal, vol. 91, no. 6, pp. 2275-2281, 2006.

[96] R. Lal, H. Lin, and A. P. Quist, "Amyloid beta ion channel: 3D structure and relevance to amyloid channel paradigm," Biochimica et Biophysica Acta, vol. 1768, no. 8, pp. 1966-1975, 2007.

[97] R. W. Carrell and D. A. Lomas, "Conformational disease," Lancet, vol. 350, no. 9071, pp. 134-138, 1997.
[98] J. Seelig, R. Lehrmann, and E. Terzi, "Domain formation induced by lipid-ion and lipid-peptide interactions," Molecular membrane biology, vol. 12, no. 1, pp. 51-57, 1995.

[99] K. S. Vetrivel and G. Thinakaran, "Membrane rafts in Alzheimer's disease beta-amyloid production," Biochimica et Biophysica Acta, vol. 1801, no. 8, pp. 860-867, 2010.

[100] K. Yanagisawa, A. Odaka, N. Suzuki, and Y. Ihara, "GM1 ganglioside-bound amyloid $\beta$-protein ( $\mathrm{AB})$ : a possible form of preamyloid in Alzheimer's disease," Nature Medicine, vol. 1, no. 10, pp. 1062-1066, 1995.

[101] A. Kakio, S. I. Nishimoto, K. Yanagisawa, Y. Kozutsumi, and K. Matsuzaki, "Cholesterol-dependent formation of GM1 ganglioside-bound amyloid $\beta$-protein, an endogenous seed for Alzheimer amyloid," Journal of Biological Chemistry, vol. 276, no. 27, pp. 24985-24990, 2001.

[102] K. Matsuzaki, K. Kato, and K. Yanagisawa, "A $\beta$ polymerization through interaction with membrane gangliosides," Biochimica et Biophysica Acta, vol. 1801, no. 8, pp. 868-877, 2010.

[103] T. L. Williams, I. J. Day, and L. C. Serpell, "The effect of Alzheimer's $A \beta$ aggregation state on the permeation of biomimetic lipid vesicles," Langmuir, vol. 26, no. 22, pp. 17260-17268, 2010.

[104] I. Peters, U. Igbavboa, T. Schütt et al., "The interaction of beta-amyloid protein with cellular membranes stimulates its own production," Biochimica et Biophysica Acta, vol. 1788, no. 5, pp. 964-972, 2009.

[105] S. Yokoyama, Y. Ohta, H. Sakai, and M. Abe, "Effect of membrane composition on surface states of ganglioside G/dipalmitoylphosphatidylcholine/dioleoylphosphatidylcholine monolayers," Colloids and Surfaces B, vol. 34, no. 1, pp. 65-68, 2004.

[106] I. Ohtsuka and S. Yokoyama, "Penetration of bovine serum albumin into dipalmitoylphosphatidylglycerol monolayers: Direct observation by atomic force microscopy," Chemical and Pharmaceutical Bulletin, vol. 53, no. 1, pp. 42-47, 2005.

[107] M. Kato-Negishi and M. Kawahara, "Neurosteroids block the increase in intracellular calcium level induced by Alzheimer's $\beta$-amyloid protein in long-term cultured rat hippocampal neurons," Neuropsychiatric Disease and Treatment, vol. 4, no. 1, pp. 209-218, 2008.

[108] F. Malchiodi-Albedi, V. Contrusciere, C. Raggi et al., "Lipid raft disruption protects mature neurons against amyloid oligomer toxicity," Biochimica et Biophysica Acta, vol. 1802, no. 4, pp. 406-415, 2010.

[109] R. Williamson, A. Usardi, D. P. Hanger, and B. H. Anderton, "Membrane-bound $\beta$-amyloid oligomers are recruited into lipid rafts by a fyn-dependent mechanism," FASEB Journal, vol. 22, no. 5, pp. 1552-1559, 2008.

[110] D. Allende, S. A. Simon, and T. J. McIntosh, "Melittininduced bilayer leakage depends on lipid material properties: evidence for toroidal pores," Biophysical Journal, vol. 88, no. 3, pp. 1828-1837, 2005.

[111] M. C. A. Lin and B. L. Kagan, "Electrophysiologic properties of channels induced by A $\beta 25-35$ in planar lipid bilayers," Peptides, vol. 23, no. 7, pp. 1215-1228, 2002.

[112] N. Arispe and M. Doh, "Plasma membrane cholesterol controls the cytotoxicity of Alzheimer's disease A $\beta \mathrm{P}(1-40)$ and (1-42) peptides," FASEB Journal, vol. 16, no. 12, pp. 1526-1536, 2002.

[113] Y. Zhou and J. S. Richardson, "Cholesterol protects PC12 cells from $\beta$-amyloid induced calcium disordering and cytotoxicity," NeuroReport, vol. 7, no. 15-17, pp. 2487-2490, 1996. 
[114] G. P. Eckert, N. J. Cairns, A. Maras, W. F. Gattaz, and W. E. Müller, "Cholesterol modulates the membrane-disordering effects of beta-amyloid peptides in the hippocampus: specific changes in Alzheimer's disease," Dementia and Geriatric Cognitive Disorders, vol. 11, no. 4, pp. 181-186, 2000.

[115] E. H. Corder, A. M. Saunders, W. J. Strittmatter et al., "Gene dose of apolipoprotein E type 4 allele and the risk of Alzheimer's disease in late onset families," Science, vol. 261, no. 5123, pp. 921-923, 1993.

[116] C. Hertel, E. Terzi, N. Hauser, R. Jakob-Røtne, J. Seelig, and J. A. Kemp, "Inhibition of the electrostatic interaction between $\beta$-amyloid peptide and membranes prevents $\beta$-amyloidinduced toxicity," Proceedings of the National Academy of Sciences of the United States of America, vol. 94, no. 17, pp. 9412-9416, 1997.

[117] T. I. Rokitskaya, Y. N. Antonenko, and E. A. Kotova, "Effect of the dipole potential of a bilayer lipid membrane on gramicidin channel dissociation kinetics," Biophysical Journal, vol. 73, no. 2, pp. 850-854, 1997.

[118] M. Vey, S. Pilkuhn, H. Wille et al., "Subcellular colocalization of the cellular and scrapie prion proteins in caveolae-like membranous domains," Proceedings of the National Academy of Sciences of the United States of America, vol. 93, no. 25, pp. 14945-14949, 1996.

[119] T. Miura, M. Yoda, N. Takaku, T. Hirose, and H. Takeuchi, "Clustered negative charges on the lipid membrane surface induce $\beta$-sheet formation of prion protein fragment 106126," Biochemistry, vol. 46, no. 41, pp. 11589-11597, 2007.

[120] M. Wakabayashi and K. Matsuzaki, "Ganglioside-induced amyloid formation by human islet amyloid polypeptide in lipid rafts," FEBS Letters, vol. 583, no. 17, pp. 2854-2858, 2009.

[121] E. Di Pasquale, J. Fantini, H. Chahinian, M. Maresca, N. Taïeb, and N. Yahi, "Altered ion channel formation by the Parkinson's-disease-linked E46K mutant of $\alpha$-synuclein is corrected by GM3 but not by GM1 gangliosides," Journal of Molecular Biology, vol. 397, no. 1, pp. 202-218, 2010.

[122] W. J. Cho, S. Trikha, and A. M. Jeremic, "Cholesterol regulates assembly of human islet amyloid polypeptide on model membranes," Journal of Molecular Biology, vol. 393, no. 3, pp. 765-775, 2009.

[123] N. Arispe, J. C. Diaz, and M. Flora, "Efficiency of histidineassociating compounds for blocking the Alzheimer's $\mathrm{A} \beta$ channel activity and cytotoxicity," Biophysical Journal, vol. 95, no. 10, pp. 4879-4889, 2008.

[124] N. Arispe, J. Diaz, S. R. Durell, Y. Shafrir, and H. R. Guy, "Polyhistidine peptide inhibitor of the $A \beta$ calcium channel potently blocks the $\mathrm{A} \beta$-induced calcium response in cells. Theoretical modeling suggests a cooperative binding process," Biochemistry, vol. 49, no. 36, pp. 7847-7853, 2010.

[125] J. C. Diaz, O. Simakova, K. A. Jacobson, N. Arispe, and H. B. Pollard, "Small molecule blockers of the Alzheimer $\mathrm{A} \beta$ calcium channel potently protect neurons from $\mathrm{A} \beta$ cytotoxicity," Proceedings of the National Academy of Sciences of the United States of America, vol. 106, no. 9, pp. 3348-3353, 2009.

[126] K. P. Whiting, C. J. Restall, and P. F. Brain, "Steroid hormoneinduced effects on membrane fluidity and their potential roles in non-genomic mechanisms," Life Sciences, vol. 67, no. 7, pp. 743-757, 2000.

[127] K. Tsutsui, K. Ukena, M. Usui, H. Sakamoto, and M. Takase, "Novel brain function: biosynthesis and actions of neurosteroids in neurons," Neuroscience Research, vol. 36, no. 4, pp. 261-273, 2000.
[128] I. Charalampopoulos, V. I. Alexaki, C. Tsatsanis et al., "Neurosteroids as endogenous inhibitors of neuronal cell apoptosis in aging," Annals of the New York Academy of Sciences, vol. 1088, pp. 139-152, 2006.

[129] S. Aldred and P. Mecocci, "Decreased dehydroepiandrosterone (DHEA) and dehydroepiandrosterone sulfate (DHEAS) concentrations in plasma of Alzheimer's disease (AD) patients," Archives of Gerontology and Geriatrics, vol. 51, no. 1, pp. e16-e18, 2010.

[130] P. Nilsson, N. Iwata, S. I. Muramatsu, L. O. Tjernberg, B. Winblad, and T. C. Saido, "Gene therapy in Alzheimer's disease-potential for disease modification," Journal of Cellular and Molecular Medicine, vol. 14, no. 4, pp. 741-757, 2010.

[131] G. K. Gouras, D. Tampellini, R. H. Takahashi, and E. Capetillo-Zarate, "Intraneuronal $\beta$-amyloid accumulation and synapse pathology in Alzheimer's disease," Acta Neuropathologica, vol. 119, no. 5, pp. 523-541, 2010.

[132] B. O’Nuallain, D. B. Freir, A. J. Nicoll et al., "Amyloid $\beta$ protein dimers rapidly form stable synaptotoxic protofibrils," Journal of Neuroscience, vol. 30, no. 43, pp. 14411-14419, 2010.

[133] D. Lindholm, H. Wootz, and L. Korhonen, "ER stress and neurodegenerative diseases," Cell Death and Differentiation, vol. 13, no. 3, pp. 385-392, 2006. 


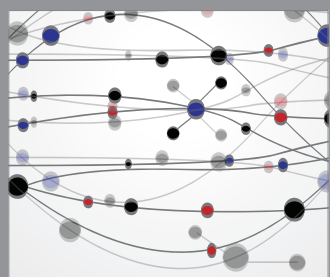

The Scientific World Journal
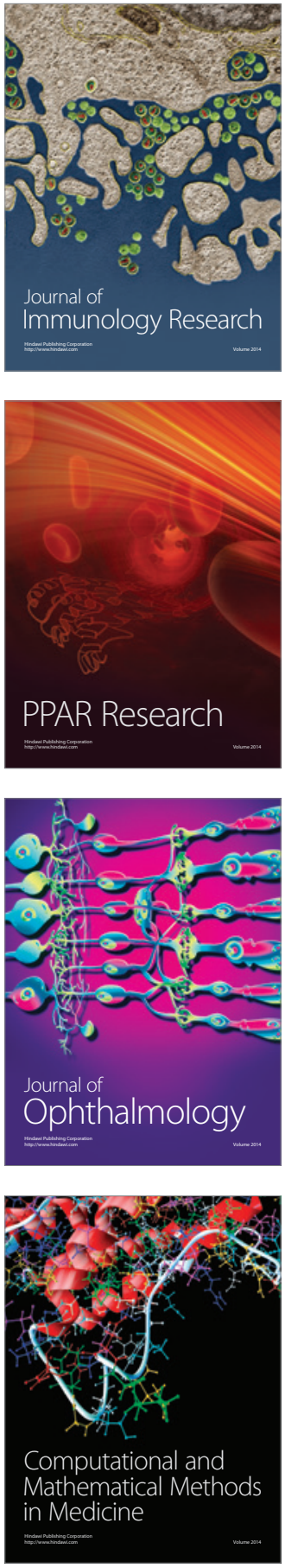

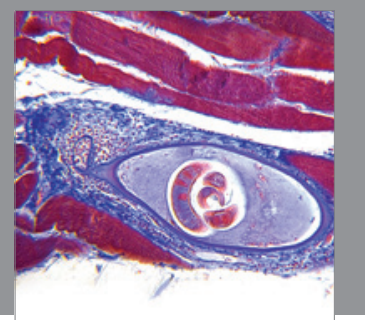

Gastroenterology

Research and Practice
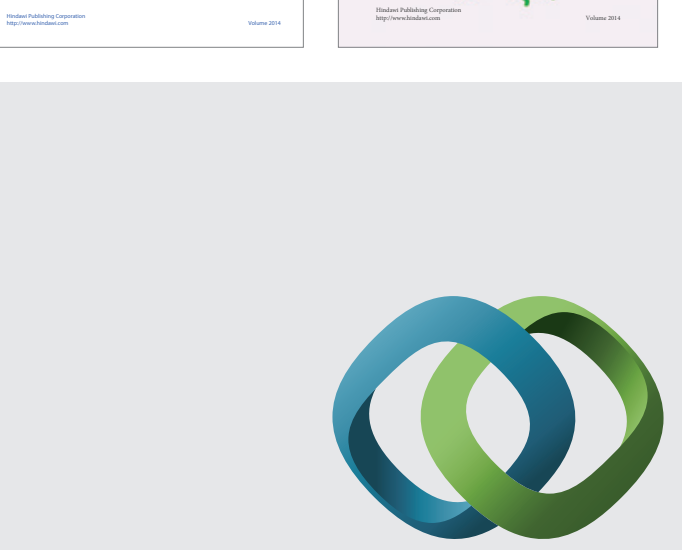

\section{Hindawi}

Submit your manuscripts at

http://www.hindawi.com
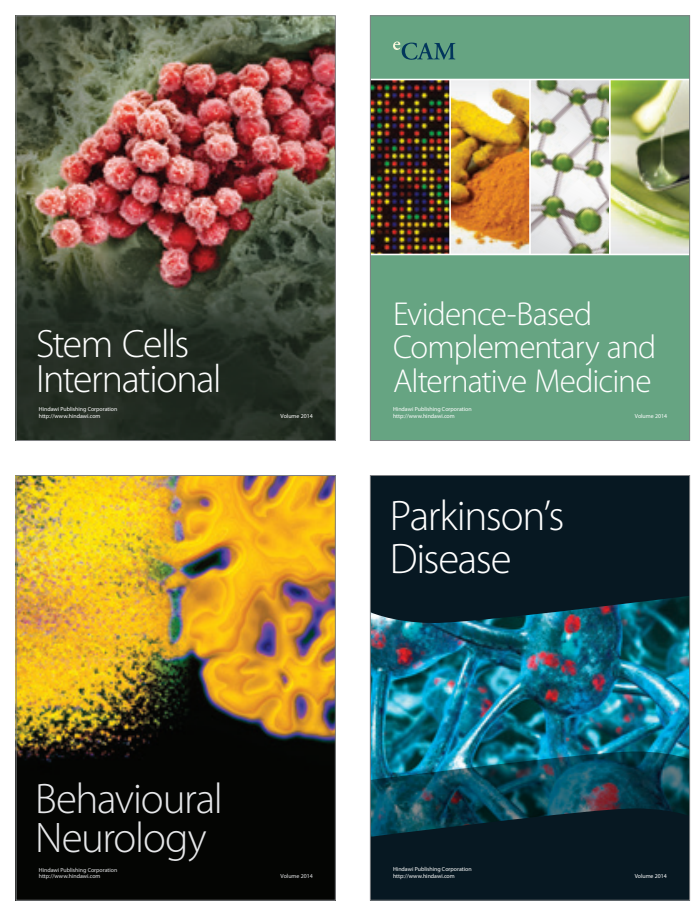

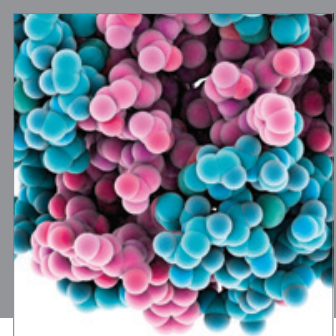

Journal of
Diabetes Research

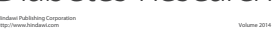

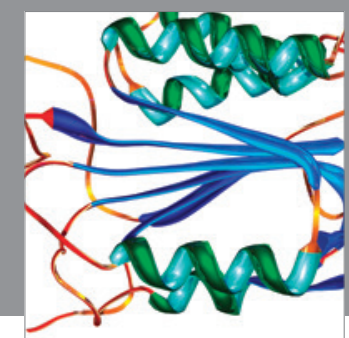

Disease Markers
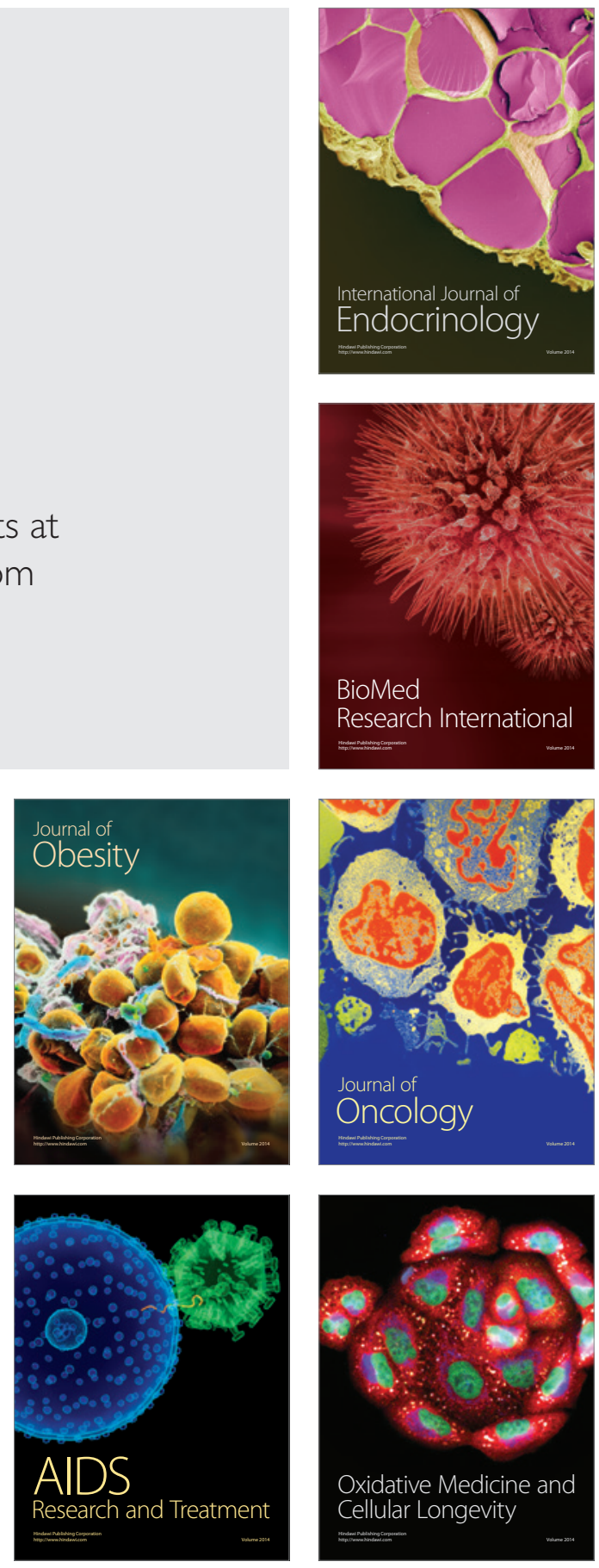